\title{
Peptide and peptidomimetic ligands for CXC chemokine receptor 4 (CXCR4).
}

\author{
$\operatorname{AUTHOR}(\mathrm{S})$ :
}

Oishi, Shinya; Fujii, Nobutaka

\section{CITATION:}

Oishi, Shinya ... [et al]. Peptide and peptidomimetic ligands for CXC chemokine receptor 4 (CXCR4).. Organic \& biomolecular chemistry 2012, 10(30): 5720-5731

\section{ISSUE DATE:}

2012-03-19

URL:

http://hdl.handle.net/2433/172240

\section{RIGHT:}

(C) The Royal Society of Chemistry 2012.; この論文は出版社版でありま せん。引用の際には出版社版をご確認じ利用ください。; This is not the published version. Please cite only the published version. 
Peptide and Peptidomimetic Ligands for CXC Chemokine Receptor 4 (CXCR4)

Shinya Oishi and Nobutaka Fujii*

Graduate School of Pharmaceutical Sciences, Kyoto University, Sakyo-ku, Kyoto 606-8501, Japan

This article is dedicated to the 10th anniversary of Organic \& Biomolecular Chemistry.

Corresponding Author:

Nobutaka Fujii, Ph.D.

Graduate School of Pharmaceutical Sciences

Kyoto University

Sakyo-ku, Kyoto 606-8501, Japan

Tel: +81-75-753-4551; Fax: +81-75-753-4570

E-mail: nfujii@pharm.kyoto-u.ac.jp 


\begin{abstract}
The development of novel peptide and peptidomimetic ligands for the CXC chemokine receptor 4 (CXCR4) as therapeutic agents for HIV-1 infection, cancer, and immune system diseases has grown over the last decade. In this perspective article, the design of CXCR4 agonists and antagonists from endogenous stromal cell-derived factor-1 (SDF-1)/CXCL12 and horseshoe crab-derived antimicrobial peptides and their therapeutic and diagnostic applications are described.
\end{abstract}

\title{
1. Introduction
}

CXC chemokine receptor 4 (CXCR4) is a G protein-coupled receptor (GPCR) of stromal cell-derived factor-1 (SDF-1)/CXCL12, ${ }^{1}$ which has been implicated in a number of developmental and physiological processes including directed migrations of stem cells and immune cells. ${ }^{2}$ In terms of a target molecule in drug discovery, CXCR4 is well-known to be a co-receptor for human immunodeficiency virus type-1 (HIV-1) infection into $\mathrm{T}$ cells. ${ }^{3}$ Compounds exerting inhibitory activity on the gp120-CXCR4 interaction have been considered as promising anti-HIV agents, because attachment of envelope glycoprotein gp120 of HIV-1 to CD4 and CXCR4 on the host cell surface is a critical step leading to membrane fusion and virus entry.

The organ-specific metastasis of breast cancer cells was first documented in $2001 .^{4}$ It was demonstrated that CXCR4-expressing cancer cells migrate based on the magnitude of the concentration gradient of SDF-1 from the distant metastatic lesions. ${ }^{4}$ During the last decade, the clinical importance and therapeutic implications of the pivotal SDF-1/CXCR4 interaction in cancer biology including progression, metastasis and angiogenesis, have been revealed. ${ }^{5} \mathrm{CXCR} 4$ antagonists are expected to behave as anti-tumor and anti-metastatic agents in cancer chemotherapy. ${ }^{6}$

To date, a number of CXCR4 ligands (agonists and antagonists) have been reported. The most representative agent is the small-molecule CXCR4 antagonist, plerixafor (Mozobil, AMD3100), which was approved for clinical use in the United States and in Europe in 2008 and 2009, respectively. ${ }^{7}$ Although plerixafor was originally developed as an anti-HIV agent, it is now employed for the mobilization of hematopoietic stem cells (HSC) into the peripheral blood in combination with granulocyte colony-stimulating factor (G-CSF). Autologous transplantation of HSC facilitates the restoration of normal hematopoietic function in patients with non-Hodgkin's lymphoma and multiple myeloma after receiving high-dose chemotherapy. Several other peptide and non-peptide CXCR4 antagonists have also been reported to be inhibitory compounds for CXCR4-mediated HIV-1 infection. $^{8}$

In this review article, we focus on the development of peptide and peptidomimetic CXCR4 ligands, which are mainly derivatives of horseshoe crab-derived antimicrobial peptides or the endogenous SDF-1 sequence. The application of these ligands as therapeutic and diagnostic agents for immune 
system diseases and oncologic conditions are also introduced.

\section{CXCR4 antagonists derived from self-defense peptides of horseshoe crabs}

\subsection{Identification of $\mathrm{T} 22$ and the derivatives: the first generation of CXCR4 antagonists}

In 1991, Morimoto et al. reported that tachyplesin I showed antiviral activity against HIV-1, vesicular stomatitis virus and influenza A virus. ${ }^{9}$ Subsequently, the anti-HIV activity of the isopeptides of tachyplesin I such as tachyplesin II and polyphemusin I and II, which were isolated from the hemocytes of horseshoe crabs (Tachypleus tridentatus and Limulus polyphemus), ${ }^{10}$ were reported (Table 1). ${ }^{11}$ These antimicrobial peptides contain two disulfide bridges which stabilize the antiparallel $\beta$-sheet structure connected by a $\beta$-turn.

$\mathrm{T} 22\left(\left[\mathrm{Tyr}^{5,12}\right.\right.$,Lys $\left.^{7}\right]$-polyphemusin II) is a first-generation peptide of highly potent anti-HIV peptides that was designed from horseshoe crab-derived natural product peptides. ${ }^{11,12}$ On the basis of the highly cationic sequences of tachyplesins and polyphemusins, more than twenty analogs were synthesized and evaluated. Among the peptides, T22 showed excellent anti-HIV activity with a high selectivity index. The solution structure of T22 takes an anti-parallel $\beta$-sheet structure, which is similar to that of tachyplesin I. ${ }^{13}$ Given the attractive lead-like properties of the T22 peptide for anti-HIV agents, intensive structural analysis and structure-activity relationship (SAR) studies have been conducted. The stereochemically antipodal peptide of T22 (all-D-isomer) was 8.5-fold less potent in comparison with the parent T22. Peptides with retro- and retro/inverse-sequences were much less potent, suggesting that the target molecule(s) of T22 should be the chiral components on host cells or virus. ${ }^{14}$ SAR study of T22 demonstrated that the two disulfide bridges and two repeated Tyr-Arg-Lys (Y-R-K) motifs are indispensable to the anti-HIV activity of T22. ${ }^{15}$ The disulfide bonds are substituted with a $\mathrm{Zn}(\mathrm{II})$ ion to form a tetracoordinate complex with equipotent anti-HIV activity. ${ }^{16}$ Substitution of $\operatorname{Trp}^{3}$ with 3-(2-naphthyl)alanine (Nal) in T22 led to the most potent T22 analogue. ${ }^{15 \mathrm{~b}}$

The target molecule of T22 for the anti-HIV activity was originally thought to be cell surface CD4 on T-cells or viral gp120. Weeks et al. reported that a phorbol ester stimulates the attachment of lymphocytes to T22, suggesting the presence of a cell surface receptor for T22. ${ }^{17}$ In contrast, CD4-negative HeLa and U87MG cells did not bind to $\mathrm{T} 22 .{ }^{18}$ In an affinity chromatography experiment, a $55 \mathrm{kDa}$ molecule, which was captured using a T22 affinity column, was detected with anti-CD4 antibody by western blotting. ${ }^{18}$ Biosensor analysis by surface plasmon resonance also demonstrated that T22 binds to both immobilized CD4 and gp120 with the same affinity. ${ }^{19}$ It was subsequently revealed in 1997 that the anti-HIV activity of T22 was derived from CXCR4 binding. ${ }^{20}$ T22 specifically inhibits the T-cell line-tropic (T-tropic) HIV-1 infection to the cells expressing CXCR4 and CD4, whilst no inhibitory effect by T22 was observed against infection of macrophage-tropic (M-tropic) HIV-1 to CCR5-expressing cells. T22 also inhibits SDF-1 $\alpha$-induced 
$\mathrm{Ca}^{2+}$ mobilization, chemotaxis of peripheral blood mononuclear cells (PBMC) and migration of pancreatic cancer cell lines through binding to CXCR4. ${ }^{21}$

\subsection{Design of T140 and its derivatives: the second generation of CXCR4 antagonists}

In an attempt to reduce the molecular size of T22, a second generation of polyphemusin II-derived CXCR4 antagonist was identified (Table 1). ${ }^{22}$ During the molecular design from T22, the outer disulfide bond, that is more conductive to the anti-parallel $\beta$-sheet structure and two repeats of indispensable Tyr-Arg-Lys (Y-R-K) sequences were retained to reproduce the potent anti-HIV activity. In addition, the $\beta$-turn moiety of T22 was stabilized using turn-stabilizing motifs, such as D-Lys-Pro or Pro-D-Lys sequences. TW70 (des-Cys ${ }^{8,13}, \mathrm{Tyr}^{9,12}$-[D-Lys $\left.{ }^{10}, \mathrm{Pro}^{11}\right]-\mathrm{T} 22$ ) was the first 14-residue CXCR4 antagonist, which showed bioactivity comparable to that of T22. ${ }^{22}$ Analysis by CD and NMR spectroscopies revealed that TW70 maintains an antiparallel $\beta$-sheet structure with a type II' $\beta$-turn motif. $^{23}$

Following on from the milestone discovery of TW70, intensive SAR studies of 14-residue $\beta$-sheet peptides have been carried out. The first approach was taken for the purpose of designing low cytotoxic analogues. $^{24}$ TW70 contains a number of basic amino acid residues (five Arg and three Lys residues) which may be related to the high level of collateral cytotoxicity. To decrease the number of these positively charged functional groups, substitutions with glutamic acid (Glu) and citrulline (Cit) were attempted. From a collection of 20 peptides designed, T134 ([Cit $\left.\left.{ }^{12}\right]-\mathrm{TW} 70\right)$ showed more potent anti-HIV activity and significantly less cytotoxicity [selectivity index (SI) $=34,000$ ] when compared with T22 and TW70. ${ }^{24}$ Of interest, T134 is effective even against drug-resistant HIV strains which were non-responsive to the small-molecule CXCR4 antagonist AMD3100. ${ }^{25}$

T140 is a key 14-residue peptide CXCR4 antagonist that was obtained by lead optimization of TW70 derivatives, ${ }^{26}$ in which the Trp $^{3}$ of T134 was substituted with Nal, in a modification similar to that of $\mathrm{T} 22 .{ }^{15 \mathrm{~b}} \mathrm{The}$ significant contribution of $\mathrm{Nal}^{3}$ to the potent bioactivity was demonstrated by the subsequent SAR study at the 3-position of T140 of inhibitory activity on SDF-1-induced Ca ${ }^{2+}$ mobilization and anti-HIV activity. ${ }^{27}$ Although both T22 and T140 upregulate the provirus transcription level driven by the HIV-1 long terminal repeat (LTR) promoter, ${ }^{28}$ the binding of anti-CXCR4 monoclonal antibody 12G5 was more efficiently inhibited by T140 than by T22, suggesting that the potent anti-HIV activity of T140 was derived from the enhanced binding affinity to CXCR4.$^{29}$ It is worthy of note that T140 is an inverse agonist for a constitutively active mutant (CAM) of CXCR4, whilst AMD3100 is a weak partial agonist. ${ }^{30}$

Alanine scanning experiments of $\mathrm{T} 140$ identified $\mathrm{Arg}^{2}, \mathrm{Nal}^{3}, \mathrm{Tyr}^{5}, \mathrm{Arg}^{14}$ residues as indispensable to the bioactivity. ${ }^{31}$ An NMR-based conformational study suggested that these intrinsic residues exist in close proximity to a disulfide bridge. ${ }^{32}$ In contrast, modifications at the $\beta$-turn moiety of T140 with 
peptide backbone mimetics had little effect on CXCR4 binding and anti-HIV activity. ${ }^{33}$ In little of this information, further optimization of T140 was conducted using two separate approaches. The first approach was focused on the design of less cytotoxic and biologically stable analogues. C-terminally amidated T140 analogues were designed, in which one or two Arg residue(s) were substituted with Cit to further reduce the cytotoxicity, because the C-terminal Arg14 in T140 was gradually cleaved in serum. ${ }^{34}$ TN14003 ([Cit $\left.{ }^{6}\right]-\mathrm{T} 140$ with the $\mathrm{C}$-terminal amide) and TC14012 ([Cit $\left.{ }^{6}, \mathrm{D}-\mathrm{Cit}^{8}\right]-\mathrm{T} 140$ with the C-terminal amide) showed high selectivity indexes (SIs) and complete stability in serum. ${ }^{34}$ Substitution of D-Lys ${ }^{8}$ with the negatively charged D-Glu ${ }^{8}$ was also effectively enhanced the anti-HIV activity whilst lowering cytotoxicity to provide TE14011 ([Cit $\left.{ }^{6}, \mathrm{D}-\mathrm{Glu}^{8}\right]-\mathrm{T} 140$ with the C-terminal amide). ${ }^{35}$ The second approach was the attachment of an additional functional group onto the T140 $\mathrm{N}$-terminus. An SAR study using a wide variety of the acyl groups revealed that the 4-fluorobenzoyl group constituted a novel pharmacophore for T140-based CXCR4 antagonists, providing the most potent antagonist, TF14016 (4-fluorobenzoyl-TN14003), with subnanomolar inhibition of the binding of SDF-1 to CXCR4. ${ }^{36}$

T140 and related peptides have been further researched for applications in a number of basic biology and drug discovery approaches including effective inhibition of SDF-1-induced cell migration of breast and prostate cancers, ${ }^{37}$ prevention of pulmonary metastasis of melanoma cells, ${ }^{38}$ and suppression of rheumatoid arthritis. ${ }^{39}$ More efficient mobilization of stem cells from bone marrow was reported by TF14016 compared with plerixafor/AMD3100. ${ }^{40}$ It was also demonstrated that T140 serves as a cargo molecule carrying anti-HIV agents such as azidothymidine (AZT) to the target cells. $^{41}$ In a separate experiment, Ichiyama et al. reported that small-molecule KRH-1636, which mimics the N-terminal motif of T140, is a potent and selective CXCR4 antagonist with high anti-HIV activity $^{42}$

Prior to the recent publication of X-ray crystallography analysis of CXCR4 (Figure 1), ${ }^{43}$ there had been several attempts made to estimate the binding mode of T140 derivatives. For example, intensive point mutation experiments of CXCR4 identified the residues responsible for ligand binding. ${ }^{44}$ It was demonstrated in fusion assays using the HIV-1 89.6 envelope glycoprotein, that conversion of Asp171, Arg188, Tyr190, Gly207, or Asp262 to Ala led to the loss of T140 bioactivity. This suggested that these five residues were critical for T140 binding. On the basis of these experiments, a docking model was created, in which the key T140 residues all interacted with the residues in the N-terminus, the 4th and 5th transmembrane domains (TM4 and TM5), extracellular loop 2 (EL2) and EL3 of CXCR4.

To date, two experiments have been reported using a photolabeling approach to determine the CXCR4 binding sites of T140. Using photoaffinity probes ${ }^{125} \mathrm{I}-\left[\mathrm{Bpa}^{5}\right]-\mathrm{T} 140$ and ${ }^{125} \mathrm{I}-\left[\mathrm{Bpa}^{10}\right]-\mathrm{T} 140$ [p-benzoyl-L-phenylalanine (Bpa)], a fragment of Lys154-Glu179 in CXCR4 4TM was identified as the interactive site of T140. ${ }^{45}$ In contrast, Grunbeck et al. employed several Bpa-containing CXCR4 
mutants, which were constructed using stop codon suppression technology. From the eight positions substituted, Phe189 in EL2 was identified as the binding site of T140. ${ }^{46}$

In a recent report on the crystal structure of CXCR4 in complex with a T140 analogue peptide, CVX15, the binding mode of the polyphemusin II-derived CXCR4 antagonists was clearly revealed (Figure I, PDB code: 3OE0). ${ }^{43} \mathrm{CVX} 15$ was bound to the receptor with the key residues $\left(\mathrm{Arg}^{2}, \mathrm{Nal}^{3}\right.$, $\mathrm{Tyr}^{5}$ and $\mathrm{Arg}^{14}$ ) inside the receptor pocket and the $\beta$-turn site exposed to the extracellular milieu. The $\mathrm{Arg}^{1}, \mathrm{Arg}^{2}$ and $\mathrm{Arg}^{14}$ residues in CVX15 interacted with Asp187, Asp171 and Asp262, respectively, and the hydrophobic group of CVX15 Nal${ }^{3}$ was anchored in the hydrophobic region of TM5.

\subsection{Identification of a novel cyclic pentapeptide scaffold for CXCR4 antagonists: the third generation of antagonists}

FC131 [cyclo(-D-Tyr-Arg-Arg-Nal-Gly-)] is a cyclic pentapeptide-based CXCR4 antagonist, which was developed using a molecular-size reduction approach (Table 1). Using the four indispensable residues (Tyr, Nal, and two Arg) in T140 and an additional Gly linker, bioevaluation of two cyclic pentapeptide libraries led to the identification of an anti-HIV peptide with CXCR4 antagonism, which was equipotent to the parent T140. ${ }^{47}$ Further SAR studies of cyclic pentapeptides including alanine-scanning, $N$-methyl amino acid scanning, optimization of amino acids and design of retro-inverso sequence peptides suggested the indispensable side-chain functional groups and potential bioactive conformations of FC131. ${ }^{48}$ FC122 [cyclo(-D-Tyr-D-MeArg-Arg-Nal-Gly-)] is the most potent cyclic pentapeptide-based CXCR4 antagonist. ${ }^{48 c}$ Recently, the in vivo inhibitory effects on the growth of GH3 somatotrope tumor cell xenografts by one of the analogous peptide FC092 ([D-Arg $\left.\left.{ }^{2}\right]-F C 131\right)$ was reported. ${ }^{49}$

Several peptidomimetic analogues of FC131 have been reported (Figure 2) ${ }^{50}$ Replacements of the dipeptide unit (Nal-Gly) with a $\gamma$-amino acid $\mathbf{1}$, disulfide bridge $\mathbf{2}$ and olefin bridge $\mathbf{3}$ have provided novel scaffold structures. ${ }^{50 \mathrm{a}}$ Cluzeau et al. reported 11 -membered ring core peptidomimetic 4 with the key functional groups, which were prepared by a divergent methodology from L- and D-glutamic acids and by ring closing metathesis. ${ }^{50 \mathrm{c}}$ Modification of FC131 with alkene-type dipeptide isosteres ( $\mathbf{5}$ and 6) has also been conducted to investigate the possible hydrogen bonding contributions of each peptide bond. ${ }^{50 \mathrm{~d}-\mathrm{g}}$ Some of these FC131 derivatives with the modification to the peptide backbone showed high to moderate CXCR4 antagonistic activity, although the approaches failed to improve the bioactivity of FC131 derivatives. In contrast, amidine-type peptide bond mimetics significantly improved the CXCR4 binding and anti-HIV activities of FC131 derivatives. ${ }^{51}$ On the basis of the highly basic properties of $\mathrm{T} 140$ derivatives and the known small-molecule CXCR4 antagonists, each peptide bond of the FC131 backbone was substituted with a planar and basic amidine unit to provide potent FC131 analogues. The best analogue FCA004 [cyclo(-D-Tyr-Arg-Arg-Nal- $\psi[\mathrm{C}(=\mathrm{NH})-\mathrm{NH}]-\mathrm{Gly}-)] 7$ 
exhibited a 30-fold increase in potency compared with the parent FC131.

An alternative approach for FC131-based antagonists is the design of bivalent ligands with an appropriate linker against potential dimerized CXCR4 receptors. ${ }^{52}$ Tanaka et al. reported the design of dimeric FC131 derivatives with a rigid poly(L-proline) linker to determine the distance between the two ligand binding sites of the CXCR4 dimer. When the possible linker length was in the range of 5.5 - $6.5 \mathrm{~nm}$, the maximum increase in the binding affinity to CXCR4 was observed. ${ }^{52 \mathrm{a}}$ In a further example of dimeric FC131, derivatives with a shorter spacer were designed based on the known bivalent small-molecule CXCR4 antagonists, in which diacids with a variety of carbohydrate linkers were employed to bridge the ornithine side-chains of the FC131 analogue ([D-MeOrn $\left.\left.{ }^{2}\right]-F C 131\right)$. Dimer peptides of $\left[\mathrm{D}-\mathrm{MeOrn}^{2}\right]-\mathrm{FC} 131$ with a 5 - 10 carbon atom spacer showed similarly potent bioactivity. ${ }^{52 b}$

There have been several recent reports describing the pharmacophore and binding models of FC131 derivatives using homology model $\mathrm{s}^{53}$ and crystal structures ${ }^{50 \mathrm{~g}, 52 \mathrm{~b}, 54}$ of CXCR4. Demmer et al. reported that [D-MeOrn $\left.{ }^{2}\right]-\mathrm{FC} 131$ had a similar binding mode to that of CVX15, in which two basic groups from $\mathrm{MeOrn}^{2}$ and $\mathrm{Arg}^{3}$ residues interact with the Asp187 and Asp171 residues of CXCR4, respectively. ${ }^{52 \mathrm{~b}}$ We also revealed the binding modes of FC131 and FC122 by NMR analysis and molecular modeling studies (Figure 3). ${ }^{50,54}$ The hydroxyl group of D-Tyr ${ }^{1}$ forms a hydrogen bond with Tyr45. The L-Arg ${ }^{2}$ side chain forms polar interactions with both Asp97 and Asp187 in CXCR4, and the L-Arg ${ }^{3}$ side-chain interacts with His113, Thr117, and Asp171 in CXCR4. Glu288 in CXCR4 is involved in the FC131 binding by hydrogen bond networks via two water molecules. The L-Nal ${ }^{4}$ carbonyl oxygen is involved in a hydrogen bond network including Tyr255 and Glu288 side chains via a crystal water molecule, and backbone $\mathrm{NH}$ of L-Arg ${ }^{2}$ makes another hydrogen bond network with CXCR4 Glu288 through a water molecule. FC122 binds with CXCR4 by an alternative binding mode with the flipped D-Tyr ${ }^{1}$-D-MeArg ${ }^{2}$ peptide bond, which was obtained on the basis of the characteristic binding mode of the congeneric peptidomimetics. ${ }^{50 \mathrm{~g}}$ The D-Tyr ${ }^{1}$ carbonyl oxygen in FC122 formed a hydrogen bond network via a water molecule.

\section{4. $\beta$-Hairpin peptidomimetic CXCR4 antagonists}

DeMarco et al. reported the identification of potent $\beta$-hairpin CXCR4 antagonists ${ }^{55}$ using a macrocyclic peptide template of $\beta$-hairpin protein epitope mimetics (PEM). ${ }^{56}$ In the $\beta$-hairpin PEM design, the template D-Pro-L-Pro dipeptide can stabilize a type-II' $\beta$-turn substructure. In addition, a disulfide bridge between two cysteine residues in each strand contributed to the stabilization of the $\beta$-hairpin conformation of the macrocyclic peptide. The loop sequence from the protein/peptide of interest could be incorporated into the other residues.

In the first step to design $\beta$-hairpin PEM molecules for CXCR4 antagonists from T140 derivatives, 
D-Cit-L-Pro dipeptide in TC14011 was substituted with a D-Pro-L-Pro peptide template to provide an equipotent peptide POL1638 (Figure 4). Development of the appropriate linker unit for macrocyclization was then explored using a peptidomimetic library. The Gly-D-Pro dipeptide linkage between the N- and C-termini of POL1638 gave the bicyclic peptides, POL2438 and POL3026, with a ten-fold increase in potency. The macrocyclic structure of both peptides resulted higher plasma and metabolic stabilities. In vivo pharmacokinetic experiment on POL3026 demonstrated an excellent bioavailability profile following subcutaneous administration. POL2438 and POL3026 inhibited HIV replication for a broad panel of X4 and dualtropic strains and POL3026 prevented the emergence of X4 variants from an R5 strain. ${ }^{56,57}$ The specificity for CXCR4 was verified by the inhibitory effect on staining by monoclonal antibodies for the potential receptors. As described above, the binding modes of CVX15 with CXCR4 were determined by X-ray crystallography recently (Figure 1). ${ }^{43}$ A peptide ligand CVX15 in the complex with CXCR4 is an open-chain analogue of POL3026.

The alternative CXCR4 antagonists with a $\beta$-hairpin peptidomimetic scaffold were reported by the researchers at Polyphor and the University of Zurich (Figure 4). ${ }^{58}$ The 16-residue bicyclic peptides 8 exhibited a highly potent inhibitory effect against SDF-1-mediated $\mathrm{Ca}^{2+}$ mobilization. Depsipeptides, including lactic acid (Lac) and (S)-4-amino-2-hydroxybutyric acid (Ahb) 9 also showed potent CXCR4 antagonism with good plasma stability. ${ }^{59}$ Optimization of the D-Pro-L-Pro dipeptide template provided several potent analogue peptidomimetics such as $\mathbf{1 0}$, including an $N$-alkylated Gly at the D-Pro residue. ${ }^{60}$ A recent patent reveals the SAR of the side-chain functional groups. ${ }^{61}$ The potent derivatives such as $\mathbf{1 1}$ were obtained by substitution of Gln with a modified Lys residue.

\section{Small peptide analogues of SDF-1}

Since it was demonstrated that SDF-1 prevents infection of T-cell line tropic HIV strains, ${ }^{1}$ a number of SDF-1 small peptide analogues have been designed as CXCR4 agonists and antagonists (Table 2). The structure of SDF-1 was determined by NMR spectroscopy ${ }^{62}$ and X-ray crystallography. ${ }^{63}$ SDF-1 had three structural motifs, including an $\mathrm{N}$-terminal unstructured sequence, a central $\beta$-sheet structure and a C-terminal $\alpha$-helix structure. SAR studies of SDF-1 analogues demonstrated that the disordered $\mathrm{N}$-terminal region takes on a critical role in receptor binding and activation. ${ }^{62,64}$ Crump et al. revealed that the N-terminal sequence (KPVSLSYR) and secondary region (RFFESH motif) comprise interactive residues for CXCR4, and that the N-terminal Lys1 and Pro2 residues in SDF-1 were involved in receptor activation and function. ${ }^{62}$ Substitution of Pro2 with Gly in SDF-1 $\alpha$ and SDF-1 $\beta$ prevented the chemotactic effect with potent receptor binding and the receptor internalization effect. $^{62,65}$. Heveker et al. identified several anti-HIV peptides by the screening and subsequent optimization of SDF-1 peptide fragments. ${ }^{64}$ For example, SDF-1(1-13), an N-terminal peptide of SDF-1, represents a CXCR4 agonist that induced an intracellular $\mathrm{Ca}^{2+}$ response and receptor 
desensitization of HeLa cells. In contrast, the analogous peptide L5H, in which Leu5 of SDF-1(1-13) was substituted with His, did not elicit the same $\mathrm{Ca}^{2+}$ response or desensitization with efficient inhibition of HIV-1 entry. Sachpatzidis et al. reported two 17-residue allosteric peptide agonists for CXCR4 identified from 160,000 SDF-1-derived peptides using a yeast screening system. ${ }^{66}$ RSVM was a weak partial agonist, whilst ASLW showed superagonistic activity with high chemotactic effects. It is of interest that the biological effects of RSVM and ASLW peptides were not prevented by AMD3100 and T140, suggesting binding to an alternative sites on CXCR4. However, the potencies of these SDF-1-derived short peptides were significantly lower in comparison with the native SDF-1.

To improve the bioactivity of SDF-1 N-terminal peptides, two approaches were developed to append positively charged sequences to an SDF-1 small peptide. ${ }^{67}$ On the basis of the common characteristics between the $\beta$-sheet region of SDF-1 and CXCR4 antagonists, the highly positive sequence was conjugated to the C-terminus of SDF-1(1-14). SD-2 containing the $\beta$-sheet region of SDF-1 exerted greater binding activity for CXCR4 and inhibitory activity of HIV-1 gp120-mediated cell-cell fusion than SDF(1-14). SD-4 with a nine-arginine sequence at the C-terminus is a distinct agonist that induces the intracellular $\mathrm{Ca}^{2+}$ flux showing a slow leakage in Sup T1 cells. The mechanism of the $\mathrm{Ca}^{2+}$ flux by SD-4 may be different from those in SDF-1 and SDF-1(1-14).

Luo et al. demonstrated the contribution of the C-terminal $\alpha$-helix region of SDF-1 to the bioactivity. ${ }^{68}$ NCT-tide was designed by direct conjunction of SDF(5-14) and SDF(55-67) through a four glycine linker in place of the central $\beta$-sheet region. This linker mimicked the distance between the N- and C-terminal regions of SDF-1. NCT-tide induced dose-dependent migration of sup T1 cells and intracellular $\mathrm{Ca}^{2+}$ flux. More recently, researchers at Chemokine Therapeutics have reported more potent analogues of NCT-tide. ${ }^{69}$ The C-terminal $\alpha$-helix structure in an NCT-tide derivative was stabilized by lactamization between Glu and Lys at the polar surface to provide CTCE0021 with enhanced receptor binding and potent $\mathrm{Ca}^{2+}$ mobilization. CTCE0214 is an analogous cyclic peptide, in which the two Cys residues of CTCE0021 were substituted to improve the plasma stability. ${ }^{70}$ Dose-dependent chemotaxis migration of $\mathrm{CD} 34^{+}$cells was observed in in vitro assays. Evaluation of CTCE0214 for in vivo effects in a mouse study also demonstrated increased migration of hematopoietic cells.

Loetscher et al. reported that symmetric dimer peptides of the SDF-1 N-terminus bind to CXCR4 as agonists and antagonists. ${ }^{71}$ For example, dimerization of SDF-1(1-9) at Cys9 using a disulfide bond provided SDF-1(1-9) dimer, which exhibited 10-fold more potent receptor binding for CXCR4 compared with the monomeric SDF-1(1-9). SDF-1(1-9) dimer can desensitize only CXCR4 and no other chemokine receptor including CXCR3, CCR1, CCR2 and CCR5 as native SDF-1, indicating the specificity for CXCR4. Modification of Pro2 to Gly in the SDF-1(1-9) dimer converted the ligand into an antagonist [SDF-1(1-9) P2G dimer], which did not trigger detectable chemotactic activity. 
Comparative NMR studies of the SDF(1-17) and SDF-1(1-9) dimers demonstrated both peptide molecules contained two $\beta-\alpha \mathrm{R}$ turn motifs. ${ }^{72}$

CTCE-9908 is an alternative CXCR4 antagonist with a dimerized sequence of SDF-1(1-8). ${ }^{73}$ Two peptides having P2G were loaded on $\alpha$ - and $\varepsilon$-amino groups of the C-terminal Lys. CTCE-9908 did not exert significant effects on migration and adhesion of CD $34^{+}$cells, whilst increased podia formation of CD $34^{+}$cells was observed. ${ }^{73}$ In contrast, there have been a number of reports on the inhibition of metastasis of osteosarcoma, ${ }^{74}$ melanoma, ${ }^{74}$ and breast cancer cells ${ }^{75}$ towards secondary organs such as the lung and bone. Additionally, direct effects of CXCR4 inhibition by CTCE-9908 on cancer cell proliferation have also been demonstrated. ${ }^{75 b, 75 d, 76}$ For example, Kwong et al. reported the cell death by mitotic catastrophe of ovarian cancer cells by CTCE-9908. ${ }^{76 \mathrm{a}}$

\section{Miscellaneous peptide and peptidomimetic CXCR4 ligands}

Although it is well known that SDF-1 is the sole endogenous ligand for CXCR4, the viral macrophage inflammatory protein-II (vMIP-II) encoded by Kaposi's sarcoma-associated herpesvirus is a chemokine-like protein capable of binding with CXCR4 (Table 3) ${ }^{77}$ CXCR4-selective peptides were designed from the vMIP-II sequence, because vMIP-II moderately inhibits HIV infection through CCR5 and CXCR4. Zhou et al. reported that the N-terminal 21-residue peptide of vMIP-II, named V1, blocked SDF-1-mediated chemotaxis and HIV-mediated cell-cell fusion. ${ }^{78}$ A subsequent structure-function analysis of the V1 peptide revealed that Leu1, Arg7 and Lys10 were indispensable for CXCR4 binding. V1 derivatives with substitution at Cys11 in V1 with Ala (V1-C11A) or Phe (V1-C11F) significantly improved the receptor binding. ${ }^{79}$ A vMIP-II(1-11) dimer was also designed on the basis of the success of the SDF-1(1-9) dimer peptides as CXCR4 ligands. ${ }^{80}$ Two vMIP-II(1-11) sequences were dimerized at the C-terminal Cys residue to provide vMIP-II(1-11) dimer, which exhibited slightly more potent receptor binding in comparison with the SDF-1(1-9) dimer. Interestingly, the mirror image peptide DV1 exhibited more potent CXCR4 antagonistic activity than V1. ${ }^{81}$ The short sequence analogue DV3 is also a CXCR4 antagonist with less receptor binding activity. ${ }^{81}$ NMR studies demonstrated that DV3 displayed partially structured turn conformations, ${ }^{82}$ which was consistent with the mirror image conformations of vMIP-II(1-10). ${ }^{80}$ When a part of the DV3 sequence was appended onto SDF-1(9-68), the hybrid peptide RCP222 showed the comparable receptor binding to SDF-1 $\alpha$ but no $\mathrm{Ca}^{2+}$ flux induction. ${ }^{83}$ Ligand binding site mapping using a panel of CXCR4 mutants revealed that RCP222 shared the interactive residues on CXCR4 with HIV-1 gp120 rather than the parent ligand SDF- $1 \alpha{ }^{84}$

Pepducins are synthetic lipopeptides of the intracellular loop sequence in GPCRs. ${ }^{85}$ Following penetration through the cell membrane, the pepducins interact with the intracellular component including signaling molecules to regulate signal transduction. Tchernychev et al. reported that 
ATI-2341 is a potent CXCR4 agonist to induce $\mathrm{Ca}^{2+}$ flux, chemotaxis and receptor internalization. ${ }^{86}$ The palmitic acid-conjugated 16-residue peptide in the intracellular loop 1 of CXCR4 induced the peritoneal recruitment of polymorphonuclear neutrophils in vivo. Recently, the mechanistic insights for ATI-2341 bioactivity were reported by photochemical crosslinking experiments using a photoaffinity probe ATI-2766. ${ }^{87}$ The binding site of ATI-2766 on CXCR4 was distinct from the ones of SDF-1 and T140, suggesting ATI-2341 is an allosteric agonist for CXCR4.

In a separate study, several positively charged peptides were reported to inhibit HIV-1 replication through competitive binding with CXCR4. ALX40-4C is an anti-HIV peptide, which was originally designed from the basic domain of the HIV-1 transactivation domain for an inhibitor of the Tat-TAR interaction. ${ }^{88}$ Subsequent investigations demonstrated that the anti-HIV effects of ALX40-4C against X4 and dual-tropic HIV-1 strains (but not against R5 strains) were derived from the selective binding to CXCR4 ${ }^{89}$ The binding sites of ALX40-4C for CXCR4 were overlapping with those of SDF-1 and 12G5. It is worthy of note that Zhou et al. revealed that the APJ receptor is an alternative target of ALX40-4C to block HIV gp120 binding to the cell membrane. ${ }^{90}$ On the basis of the successes in ALX40-4C and SDF-1-derived D-peptides, a library of D-amino acid decapeptides was prepared for the development of novel HIV entry inhibitors. ${ }^{91}$ Among the D-peptides tested, DC13 showed the most potent inhibitory activity against both $\mathrm{X} 4$ and R5 HIV-1 strains. The mechanism of anti-HIV activity against X4 strains was verified by the inhibitory effects for SDF-1 and 12G5 binding to CXCR4, whilst the mechanism of action for R5 strains has not been determined. $\beta$-Defensin 3 (hBD3) also inhibits SDF-1-mediated $\mathrm{Ca}^{2+}$ mobilization and ERK phosphorylation. ${ }^{92}$ The anti-HIV activity of hBD3 is derived from the receptor internalization of CXCR4 and direct interaction with HIV-1 virions. $^{92 \mathrm{a}}$

\section{Imaging probes for CXCR4}

\subsection{Radiolabeled CXCR4 probes}

The first report of the radiolabeled imaging probes for CXCR4 was the ${ }^{111}$ In-labeled T140 derivative [ ${ }^{111}$ In-DTPA-Ac-TZ14011 (DTPA: diethylenetriaminepentaacetic acid)] (Table 4, Figure 5). ${ }^{93}$ Ac-TZ14011 with a single Lys residue was designed for the site-selective conjugation of radiolabels. In the biodistribution experiments, high accumulation of ${ }^{111}$ In-DTPA-Ac-TZ14011 was observed in the CXCR4-expressing tumors compared with the blood and muscle. Recently, a more concise synthetic protocol for In-DTPA-Ac-TZ14011 was reported. ${ }^{94}$ In the article, a more potent analogue, In-DTPA-TF14016, with an N-terminal 4-fluorobenzoyl group was also described. Kuil et al. reported bimodal antagonist probes having a DTPA and a fluorescent CyAL-5.5 ${ }^{95}$ Ac-TZ14011-MSAP was prepared using a multifunctional single-attachment-point (MSAP) reagent ${ }^{96}$ and was used for SPECT/CT and fluorescent imaging. Dimeric and tetrameric Ac-TZ14011 units, 
which were conjugated to a DTPA/CyAL-5.5 MSAP reagent, were also designed to improve the receptor binding and biodistribution. ${ }^{95 \mathrm{~b}}$

Jacobson, et al. reported that a CXCR4 antagonist probe, designated T140-2D, in which two DOTA groups were appended onto $\mathrm{Lys}^{7}$ and D-Lys ${ }^{8}$ in TF14016 (DOTA: 1,4,7,10-tetraazacyclododecane-1,4,7,10-tetraacetic acid). ${ }^{97}$ Using ${ }^{64} \mathrm{Cu}$ and ${ }^{68} \mathrm{Ga}$ as radionuclei for PET imaging and biodistribution analysis, CXCR4-expressing tumors were clearly visualized, although significant accumulation in the liver and kidneys was also observed. Recently, the same group reported DOTA- and NOTA-labeled CXCR4 tracers (NOTA: 1,4,7-triazacyclononane-1,4,7-triacetic acid), which do not bind to undesired targets such as red blood cells. $^{98}$

$4-{ }^{18} \mathrm{~F}-\mathrm{T} 140$ is an alternative CXCR4 probe for PET imaging, which was designed based on the structure of TF14016. ${ }^{99}$ An ${ }^{18} \mathrm{~F}$-fluoride labeling was appended to the N-terminal 4-fluorobenzoyl group by using an $\mathrm{N}$-succimidyl $4-{ }^{18} \mathrm{~F}$-fluorobenzoate $\left({ }^{18} \mathrm{~F}\right.$-SFB) reagent. For the site-selective labeling and short-time treatment after ${ }^{18} \mathrm{~F}-\mathrm{SFB}$-mediated labeling, $N$-[1-(4,4-dimethyl-2,6-dioxocyclohex-1-ylidene)ethyl] (Dde) groups were used as protecting groups for two Lys side-chains. In PET studies and biodistribution experiments using $4-{ }^{18} \mathrm{~F}-\mathrm{T} 140$, clear visualization of CXCR4-transfected $\mathrm{CHO}$ cells with high tumor-to-muscle and tumor-to-blood ratios were observed.

Cyclic pentapeptide-based antagonist FC131 provided an alternative series of CXCR4-specific probe molecules (Figure 6). Demmer et al. reported that a DOTA-conjugated cyclic peptide ${ }^{68} \mathrm{Ga}-\mathrm{CPCR} 4-2$, in which the labeling group was appended onto the side-chain of D- $N^{\alpha}$-methylornithine (D-MeOrn) through a (4-aminomethyl)benzoic acid (Amb) linker. ${ }^{100}$ This tracer peptide showed equipotent receptor binding to the parent FC131 and high tumor accumulation. ${ }^{100,101}$ The ${ }^{68} \mathrm{Ga}$-labeled dimeric peptide $\left({ }^{68} \mathrm{Ga}-25\right)$ of the $\mathrm{FC} 131$ derivative was also designed on the basis of the known antagonists with a $C_{2}$ symmetry element, allowing visualization of an $\mathrm{OH} 1 \mathrm{~h}-\mathrm{SCLC}$ xenograft by PET imaging. ${ }^{52 b}$

\subsection{Fluorescent CXCR4 probes}

There have been several reports on fluorescent SDF-1 derivatives, which were used to detect CXCR4 expression and localization (Table 4). Dar et al. studied the internalization of SDF-1 on bone marrow endothelial cells using fluorescein isothiocyanate (FITC)-labeled SDF-1 (FITC-SDF-1). ${ }^{102}$ In confocal microscopy analysis, co-localization of the internalized FITC-SDF-1 with $\alpha$-adapton was observed, suggesting that the internalization was mediated by clathrin-coated pits. Hatse et al. evaluated the expression level of CXCR4 in peripheral blood mononuclear cells using CXCL12 ${ }^{\mathrm{AF} 647}$, in which AlexaFluor 647 was conjugated at the second residue to the C-terminus. ${ }^{103}$ The biological 
activities of CXCL12 $2^{\mathrm{AF} 647}$ including intracellular $\mathrm{Ca}^{2+}$ mobilization and MAPK phosphorylation were compatible to those of unlabeled SDF-1. Strong et al. also utilized CXCL12 ${ }^{\mathrm{AF} 647}$ for flow cytometry and binding inhibition experiments. ${ }^{104}$

Development and application of antagonist-based probes for CXCR4 have also been reported (Table 4). TY 14003 is a fluorescent T140 derivative, in which the Lys $\varepsilon$-amino group at the $\beta$-turn of Ac-TZ14011 was modified with carboxyfluorescein. ${ }^{105}$ CXCR4 expression on migrated cells in the chemotaxis experiments were clearly characterized by flow cytometry analysis using TY14003. TY14003 also labeled a CXCR4-expressing bladder cancer cell line as well as urothelial cells in urinary sediments from patients with invasive bladder cancer. ${ }^{106}$ In in vivo fluorescent labeling experiment, mouse $N$-butyl- $N$-(4-hydroxybutyl)nitrosamine (BBN)-induced bladder cancer in the focal areas was detected by intravesical administration of TY14003. ${ }^{106}$

Fluorescent labeling with TAMRA and FITC at the $\beta$-turn position of Ac-TZ14011 was also tolerated. TAMRA-Ac-TZ14011 was employed for receptor staining of NP-2 CXCR4-GFP and CCR-CD4-HeLa cells. ${ }^{107}$ When fluorescent immunohistochemistry of tumor tissue using Ac-TZ14011-FITC was performed, a different staining pattern between MDAMB231 and MDAMB231 ${ }^{\mathrm{CXCR}^{4+}}$ cells was observed. ${ }^{108}$ Luminescent iridium dye complexes of Ac-TZ14011 for CXCR4 imaging were also reported recently, in which the cyclometalated octahedral iridium(III) 2-phenylpyridine complex was modified with one or multiple Ac-TZ14011 peptides. These probes detect CXCR4 expression efficiently by confocal microscopy and flow cytometry. ${ }^{109}$

\section{Conclusions and Future Perspectives}

In this review article, the medicinal chemistry processes of peptide and peptidomimetic CXCR4 ligands have been described. Descriptions included polyphemusin II-derived antagonists, chemokine-derived agonists/antagonists and receptor fragment pepducin. Several potent substances have also been employed for the design of CXCR4 imaging probes with a variety of labeling groups for cancer diagnostics. In the last decade, considerable progress has been made in the cancer biology of CXCR4-expressing cells. These peptide and peptidomimetic ligands have served as selective inhibitors and probe molecules for basic biological and biophysical research on the SDF-1/CXCR4 axis.

Although it had been believed that SDF-1 mediated biological process via a sole receptor CXCR4, RDC1/CXCR7, an orphan GPCR, was identified as another receptor of SDF-1 in 2005. ${ }^{110}$ CXCR7 recognizes SDF-1 and interferon-inducible $\mathrm{T}$ cell $\alpha$ chemoattractant (I-TAC)/CXCL11 as the endogenous agonists and CXCR7 expression provides tumor cells with cell growth and adhesion properties. ${ }^{111,112}$ Future investigations using selective CXCR4 and CXCR7 ligands will reveal the distinct pivotal roles of SDF-1/CXCR4 and SDF-1/CXCR7 axes in the physiological and 
pathogenetical processes. 


\section{References}

1 (a) C. C. Bleul, M. Farzan, H. Choe, C. Parolin, I. Clark-Lewis, J. Sodroski, T. A. Springer. Nature, 1996, 382, 829-833; (b) E. Oberlin, A. Amara, F. Bachelerie, C. Bessia, J. L. Virelizier, F. Arenzana-Seisdedos, O. Schwartz, J. M. Heard, I. Clark-Lewis, D. F. Legler, M. Loetscher, M. Baggiolini, B. Moser. Nature, 1996, 382, 833-835.

2 For a recent review, see: N. M. Moll, R. M. Ransohoff. Expert Rev. Hematol., 2010, 3, 315-322.

3 Y. Feng, C. C. Broder, P. E. Kennedy, E. A. Berger. Science, 1996, 272, 872-877.

4 A. Müller, B. Homey, H. Soto, N. Ge, D. Catron, M. E. Buchanan, T. McClanahan, E. Murphy, W. Yuan, S. N. Wagner, J. L. Barrera, A. Mohar, E. Verástegui, A. Zlotnik. Nature, 2001, 410, 50-56.

5 (a) E. T. Roussos, J. S. Condeelis, A. Patsialou. Nat. Rev. Cancer, 2011, 11, 573-587; (b) A. Zlotnik, A. M. Burkhardt, B. Homey. Nat. Rev. Immunol., 2011, 11, 597-606.

6 For reviews, see: (a) J. A. Burger, T.J. Kipps. Blood, 2006, 107, 1761-1767; (b) Y. Lavrovsky, Y. A. Ivanenkov, K. V. Balakin, D. A. Medvedeva, A. V. Ivachtchenko. Mini Rev. Med. Chem., 2008, 8, 1075-1087; (c) H. Shim, S. Oishi, N. Fujii. Semin. Cancer Biol., 2009, 19, 123-134; (d) J. A. Burger, A. Peled. Leukemia, 2009, 23, 43-52; (e) J. A. Burger, D. J. Stewart. Expert Opin. Investig. Drugs., 2009, 18, 481-490; (f) J. A. Burger, D. J. Stewart, O. Wald, A. Peled. Expert Rev. Anticancer Ther., 2011, 11, 621-630; (g) W. Choi, S. Duggineni, Y. Xu, Z. Huang, J. An. J. Med. Chem., 2012, 55, 977-994.

7 (a) A. F. Cashen. Drugs Today, 2009, 45, 497-505; (b) A. J. Wagstaff. Drugs, 2009, 69, 319-326;

(c) E. De Clercq. Biochem. Pharmacol., 2009, 77, 1655-1664; (d) S. P. Fricker. Expert Opin. Investig. Drugs, 2008, 17, 1749-1760; (e) G. L. Uy, M. P. Rettig, A. F. Cashen. Expert Opin. Biol. Ther., 2008, 8, 1797-1804; (f) E. De Clercq. Pharmacol. Ther., 2010, 128, 509-518; (g) G. M. Keating. Drugs, 2011, 71, 1623-1647.

For recent reviews, see: (a) H. Tamamura, H. Tsutsumi, N. Fujii. Mini Rev. Med. Chem., 2006, 6, 989-995; (b) H. Tsutsumi, T. Tanaka, N. Ohashi, H. Masuno, H. Tamamura, K. Hiramatsu, T. Araki, S. Ueda, S. Oishi, N. Fujii. Biopolymers, 2007, 88, 279-289; (c) H. Tamamura, H. Tsutsumi, H. Masuno, N. Fujii. Curr. Med. Chem., 2007, 14, 93-102; (d) A. Khan, J. Greenman, S. J. Archibald. Curr. Med. Chem., 2007, 14, 2257-2277; (e) F. Grande, A. Garofalo, N. Neamati. Curr. Pharm. Des., 2008, 14, 385-404; (f) C. A. Mosley, L. J. Wilson, J. M. Wiseman, J. W. Skudlarek, D. C. Liotta. Expert Opin. Ther. Pat., 2009, 19, 23-38; (g) L. Patrussi, C. T. Baldari. Curr. Med. Chem., 2011, 18, 497-512; (h) I. P. Singh, S. K. Chauthe. Expert Opin. Ther. Pat., 2011, 21, 227-269; (i) L. E. Woodard, S. Nimmagadda. J. Nucl. Med., 2011, 52, 1665-1669.

9 M. Morimoto, H. Mori, T. Otake, N. Ueba, N. Kunita, M. Niwa, T. Murakami, S. Iwanaga. Chemotherapy, 1991, 37, 206-211. 
10 (a) T. Nakamura, H. Furunaka, T. Miyata, F. Tokunaga, T. Muta, S. Iwanaga, M. Niwa, T. Takao, Y. Shimonishi. J. Biol. Chem., 1988, 263,16709-16713; (b) T. Miyata, F. Tokunaga, T. Yoneya, K. Yoshikawa, S. Iwanaga, M. Niwa, T. Takao, Y. Shimonishi. J. Biochem., 1989, 106, 663-668.

11 M. Masuda, H. Nakashima, T. Ueda, H. Naba, R. Ikoma, A. Otaka, Y. Terakawa, H. Tamamura, T. Ibuka, T. Murakami, Y. Koyanagi, M. Waki, A. Matsumoto, N. Yamamoto, S. Funakoshi, N. Fujii. Biochem. Biophys. Res. Commun., 1992, 189, 845-850.

12 H. Nakashima, M. Masuda, T. Murakami, Y. Koyanagi, A. Matsumoto, N. Fujii, N. Yamamoto. Antimicrob. Agents Chemother., 1992, 36, 1249-1255.

13 H. Tamamura, M. Kuroda, M. Masuda, A. Otaka, S. Funakoshi, H. Nakashima, N. Yamamoto, M. Waki, A. Matsumoto, J. M. Lancelin, D. Kohda, S. Tate, F. Inagaki, N. Fujii. Biochim. Biophys. Acta., 1993, 1163, 209-216.

14 A. Otaka, H. Tamamura, Y. Terakawa, M. Masuda, T. Koide, T. Murakami, H. Nakashima, K. Matsuzaki, K. Miyajima, T. Ibuka, M. Waki, A. Matsumoto, N. Yamamoto, N. Fujii. Biol. Pharm. Bull., 1994, 17, 1669-1672.

15 (a) H. Tamamura, T. Murakami, M. Masuda, A. Otaka, W. Takada, T. Ibuka, H. Nakashima, M. Waki, A. Matsumoto, N. Yamamoto, N. Fujii. Biochem. Biophys. Res. Commun., 1994, 205, 1729-1735; (b) H. Tamamura, M. Imai, T. Ishihara, M. Masuda, H. Funakoshi, H. Oyake, T. Murakami, R. Arakaki, H. Nakashima, A. Otaka, T. Ibuka, M. Waki, A. Matsumoto, N. Yamamoto, N. Fujii. Bioorg. Med. Chem., 1998, 6, 1033-1041.

H. Tamamura, A. Otaka, T. Murakami, T. Ibuka, K. Sakano, M. Waki, A. Matsumoto, N. Yamamoto, N. Fujii. Biochem. Biophys. Res. Commun., 1996, 229, 648-652.

B. S. Weeks, M. Nomizu, A. Otaka, C. A. Weston, A. Okusu, H. Tamamura, A. Matsumoto, N. Yamamoto, N. Fujii. Biochem. Biophys. Res. Commun., 1994, 202, 470-475.

B. S. Weeks, M. Nomizu, A. Otaka, C. A. Weston, A. Okusu, H. Tamamura, N. Yamamoto, N. Fujii. Biochem .Biophys. Res. Commun., 1995, 215, 626-631.

(a) H. Tamamura, A. Otaka, T. Murakami, T. Ishihara, T. Ibuka, M. Waki, A. Matsumoto, N.Yamamoto, N. Fujii. Biochem. Biophys. Res. Commun., 1996, 219, 555-559; (b) H. Tamamura, T. Ishihara, A. Otaka, T. Murakami, T. Ibuka, M. Waki, A. Matsumoto, N. Yamamoto, N. Fujii. Biochim. Biophys. Acta., 1996, 1298, 37-44.

20 T. Murakami, T. Nakajima, Y. Koyanagi, K. Tachibana, N. Fujii, H. Tamamura, N. Yoshida, M. Waki, A. Matsumoto, O. Yoshie, T. Kishimoto, N. Yamamoto, T. Nagasawa. J. Exp. Med., 1997, 186, 1389-1393.

21 (a) T. Murakami, T. Y. Zhang, Y. Koyanagi, Y. Tanaka, J. Kim, Y. Suzuki, S. Minoguchi, H. Tamamura, M. Waki, A. Matsumoto, N. Fujii, H. Shida, J. A. Hoxie, S. C. Peiper, N. Yamamoto. J. Virol., 1999, 73, 7489-7496; (b) T. Koshiba, R. Hosotani, Y. Miyamoto, J. Ida, S. Tsuji, S. 
Nakajima, M. Kawaguchi, H. Kobayashi, R. Doi, T. Hori, N. Fujii, M. Imamura. Clin. Cancer Res., 2000, 6, 3530-3535.

M. Waki, K. Waki, K. Miyamoto, A. Matsumoto, H. Tamamura, N. Fujii, T. Murakami, H. Nakashima, N. Yamamoto. Chem. Lett., 1996, 571-572.

H. Tamamura, M. Waki, M. Imai, A. Otaka, T. Ibuka, K. Waki, K. Miyamoto, A. Matsumoto, T. Murakami, H. Nakashima, N. Yamamoto, N. Fujii. Bioorg. Med. Chem., 1998, 6, 473-479.

H. Tamamura, R. Arakaki, H. Funakoshi, M. Imai, A. Otaka, T. Ibuka, H. Nakashima, T. Murakami, M. Waki, A. Matsumoto, N. Yamamoto, N. Fujii. Bioorg. Med. Chem., 1998, 6, 231-238.

25 R. Arakaki, H. Tamamura, M. Premanathan, K. Kanbara, S. Ramanan, K. Mochizuki, M. Baba, N. Fujii, H. Nakashima. J. Virol., 1999, 73, 1719-1723.

26 H. Tamamura, Y. Xu, T. Hattori, X. Zhang, R. Arakaki, K. Kanbara, A. Omagari, A. Otaka, T. Ibuka, N. Yamamoto, H. Nakashima, N. Fujii. Biochem. Biophys. Res. Commun., 1998, 253, 877-882.

27 H. Tamamura, A. Omagari, K. Hiramatsu, S. Oishi, H. Habashita, T. Kanamoto, K. Gotoh, N. Yamamoto, H. Nakashima, A. Otaka, N. Fujii. Bioorg. Med. Chem., 2002, 10, 1417-1426.

K. Gotoh, M. Yoshimori, K. Kanbara, H. Tamamura, T. Kanamoto, K. Mochizuki, N. Fujii, H. Nakashima. J. Infect. Chemother., 2001, 7, 28-36.

29 Y. Xu, H. Tamamura, R. Arakaki, H. Nakashima, X. Zhang, N. Fujii, T. Uchiyama, T. Hattori. AIDS Res. Hum. Retrovir., 1999, 15, 419-427.

30 W. B. Zhang, J. M. Navenot, B. Haribabu, H. Tamamura, K. Hiramatu, A. Omagari, G. Pei, J. P. Manfredi, N. Fujii, J. R. Broach, S. C. Peiper. J. Biol. Chem., 2002, 277, 24515-24521.

31 H. Tamamura, A. Omagari, S. Oishi, T. Kanamoto, N. Yamamoto, S. C. Peiper, H. Nakashima, A. Otaka, N. Fujii. Bioorg. Med. Chem. Lett., 2000, 10, 2633-2637.

32 H. Tamamura, M. Sugioka, Y. Odagaki, A. Omagari, Y. Kan, S. Oishi, H. Nakashima, N. Yamamoto, S. C. Peiper, N. Hamanaka, A. Otaka, N. Fujii. Bioorg. Med. Chem. Lett., 2001, 11, 359-362.

33 H. Tamamura, K. Hiramatsu, K. Miyamoto, A. Omagari, S. Oishi, H. Nakashima, N. Yamamoto, Y. Kuroda, T. Nakagawa, A. Otaka, N. Fujii. Bioorg. Med. Chem. Lett., 2002, 12, 923-928.

34 H. Tamamura, A. Omagari, K. Hiramatsu, K. Gotoh, T. Kanamoto, Y. Xu, E. Kodama, M. Matsuoka, T. Hattori, N. Yamamoto, H. Nakashima, A. Otaka, N. Fujii. Bioorg. Med. Chem. Lett., 2001, 11, 1897-1902.

35 H. Tamamura, K. Hiramatsu, S. Kusano, S. Terakubo, N. Yamamoto, J. O. Trent, Z. Wang, S. C. Peiper, H. Nakashima, A. Otaka, N. Fujii. Org. Biomol. Chem., 2003, 1, 3656-3562.

36 H. Tamamura, K. Hiramatsu, M. Mizumoto, S. Ueda, S. Kusano, S. Terakubo, M. Akamatsu, N. 
Yamamoto, J. O. Trent, Z. Wang, S. C. Peiper, H. Nakashima, A. Otaka, N. Fujii. Org. Biomol. Chem., 2003, 1, 3663-3669.

(a) H. Tamamura, A. Hori, N. Kanzaki, K. Hiramatsu, M. Mizumoto, H. Nakashima, N. Yamamoto, A. Otaka, N. Fujii. FEBS Lett., 2003, 550, 79-83; (b) T. Mori, R. Doi, M. Koizumi, E. Toyoda, D. Ito, K. Kami, T. Masui, K. Fujimoto, H. Tamamura, K. Hiramatsu, N. Fujii, M. Imamura. Mol. Cancer Ther., 2004, 3, 29-37.

M. Takenaga, H. Tamamura, K. Hiramatsu, N.Nakamura, Y. Yamaguchi, A. Kitagawa, S. Kawai, H. Nakashima, N. Fujii, R. Igarashi. Biochem. Biophys. Res. Commun., 2004, 320, 226-232.

H. Tamamura, M. Fujisawa, K. Hiramatsu, M. Mizumoto, H. Nakashima, N. Yamamoto, A. Otaka, N. Fujii. FEBS Lett., 2004, 569, 99-104.

M. Abraham, K. Beider, H. Wald, I. D. Weiss, D. Zipori, E. Galun, A. Nagler, O. Eizenberg, A. Peled. Leukemia., 2009, 23, 1378-1388.

41 H. Tamamura, A. Omagari, K. Hiramatsu, T. Kanamoto, K. Gotoh, K. Kanbara, N. Yamamoto, H. Nakashima, A. Otaka, N. Fujii. Bioorg. Med. Chem., 2001, 9, 2179-2187.

42 K. Ichiyama, S. Yokoyama-Kumakura, Y. Tanaka, R. Tanaka, K. Hirose, K. Bannai, T. Edamatsu, M. Yanaka, Y. Niitani, N. Miyano-Kurosaki, H. Takaku, Y. Koyanagi, N. Yamamoto. Proc. Natl. Acad. Sci. USA., 2003, 100, 4185-4190.

B. Wu, E. Y. Chien, C. D. Mol, G. Fenalti, W. Liu, V. Katritch, R. Abagyan, A. Brooun, P. Wells, F. C. Bi, D. J. Hamel, P. Kuhn, T. M. Handel, V. Cherezov, R. C. Stevens. Science, 2010, 330, 1066-1071.

J. O. Trent, Z. X. Wang, J. L.Murray, W. Shao, H. Tamamura, N. Fujii, S. C. Peiper. J. Biol. Chem., 2003, 278, 47136-47144.

P. E. Boulais, D. Dulude, J. Cabana, N. Heveker, E. Escher, P. Lavigne, R. Leduc. Biochem. Pharmacol., 2009, 78, 1382-1390.

A. Grunbeck, T. Huber, P. Sachdev, T. P. Sakmar. Biochemistry, 2011, 50, 3411-3413.

N. Fujii, S. Oishi, K. Hiramatsu, T. Araki, S. Ueda, H. Tamamura, A. Otaka, S. Kusano, S. Terakubo, H. Nakashima, J. A. Broach, J. O. Trent, Z. X. Wang, S. C. Peiper. Angew. Chem. Int. Ed. Engl., 2003, 42, 3251-3253.

(a) H. Tamamura, M. Mizumoto, K. Hiramatsu, S. Kusano, S. Terakubo, N. Yamamoto, J. O. Trent, Z. Wang, S. C. Peiper, H. Nakashima, A. Otaka, N. Fujii. Org. Biomol. Chem., 2004, 2, 1255-1257; (b) H. Tamamura, A. Esaka, T. Ogawa, T. Araki, S. Ueda, Z. Wang, J. O. Trent, H. Tsutsumi, H. Masuno, H. Nakashima, N. Yamamoto, S. C. Peiper, A. Otaka, N. Fujii. Org. Biomol. Chem., 2005, 3, 4392-4394; (c) S. Ueda, S. Oishi, Z. X. Wang, T. Araki, H. Tamamura, J. Cluzeau, H. Ohno, S. Kusano, H. Nakashima, J. O. Trent, S. C. Peiper, N. Fujii. J. Med. Chem., 2007, 50, 192-198; (d) T. Tanaka, H. Tsutsumi, W. Nomura, Y. Tanabe, N. Ohashi, A. Esaka, C. 
Ochiai, J. Sato, K. Itotani, T. Murakami, K. Ohba, N. Yamamoto, N. Fujii, H. Tamamura. Org. Biomol. Chem., 2008, 6, 4374-4377; (e) T. Tanaka, W. Nomura, T. Narumi, A. Esaka, S. Oishi, N. Ohashi, K. Itotani, B. J. Evans, Z. X. Wang, S. C. Peiper, N. Fujii, H. Tamamura. Org. Biomol. Chem., 2009, 7, 3805-3809.

J. M. Kim, Y. H. Lee, C. R. Ku, E. J. Lee. Endocrinology, 2011, 152, 536-544.

(a) H. Tamamura, T.Araki, S. Ueda, Z. Wang, S. Oishi, A. Esaka, J. O.Trent, H. Nakashima, N. Yamamoto, S. C. Peiper, A.Otaka, N. Fujii. J. Med. Chem., 2005, 48, 3280-3289; (b) A. Niida, H. Tanigaki, E. Inokuchi, Y. Sasaki, S. Oishi, H. Ohno, H. Tamamura, Z. Wang, S. C. Peiper, K. Kitaura, A. Otaka, N. Fujii. J Org Chem., 2006, 71, 3942-3951; (c) J. Cluzeau, S. Oishi, H. Ohno, Z. Wang, B. Evans, S. C. Peiper, N. Fujii. Org. Biomol. Chem., 2007, 5, 1915-1923; (d) H. Tamamura, K. Hiramatsu, S. Ueda, Z. Wang, S. Kusano, S. Terakubo, J. O. Trent, S. C. Peiper, N. Yamamoto, H. Nakashima, A. Otaka, N. Fujii. J. Med. Chem., 2005, 48, 380-391; (e) T. Narumi, K. Tomita, E. Inokuchi, K. Kobayashi, S. Oishi, H. Ohno, N. Fujii. Tetrahedron, 2008, 64, 4332-4346; (f) T. Narumi, R. Hayashi, K. Tomita, K. Kobayashi, N. Tanahara, H. Ohno, T. Naito, E. Kodama, M. Matsuoka, S. Oishi, N. Fujii. Org. Biomol. Chem., 2010, 8, 616-621; (g) K. Kobayashi, S. Oishi, R. Hayashi, K. Tomita, T. Kubo, N. Tanahara, H. Ohno, Y. Yoshikawa, T. Furuya, M. Hoshino, N. Fujii. J. Med. Chem. doi: 10.1021/jm2016914.

51 E. Inokuchi, S. Oishi, T. Kubo, H. Ohno, K. Shimura, M. Matsuoka, N. Fujii. ACS Med. Chem. Lett., 2011, 2, 477-480.

52 (a) T. Tanaka, W. Nomura, T. Narumi, A. Masuda, H. Tamamura. J. Am. Chem. Soc., 2010, 132, 15899-15901; (b) O. Demmer, I. Dijkgraaf, U. Schumacher, L. Marinelli, S. Cosconati, E. Gourni, H. J. Wester, H. Kessler. JMed Chem., 2011, 54, 7648-7662.

(a) J. Våbenø, G. V. Nikiforovich G. R., Marshall. Chem. Biol. Drug Des., 2006, 67, 346-354;

(b) J. Våbenø, G. V. Nikiforovich, G. R. Marshall. Biopolymers, 2006, 84, 459-471; (c) S. P. Kawatkar, M. Yan, H. Gevariya, M. Y. Lim, S. Eisold, X. Zhu, Z. Huang, J. An. Exp. Biol. Med., 2011, 236, 844-850.

54 Y. Yoshikawa, K. Kobayashi, S. Oishi, N. Fujii, T. Furuya. Bioorg. Med. Chem. Lett., 2012, 22, 2146-2150.

55 (a) S. J. DeMarco, H. Henze, A. Lederer, K. Moehle, R. Mukherjee, B. Romagnoli, J. A. Robinson, F. Brianza, F. O. Gombert, S. Lociuro, C. Ludin, J. W. Vrijbloed, J. Zumbrunn, J. P. Obrecht, D. Obrecht, V. Brondani, F. Hamy, T. Klimkait. Bioorg. Med. Chem., 2006, 14, 8396-8404; (b) A. Lederer, S. J. DeMarco, H. Henze, B. Romagnoli, R. Mukherjee, J. Zumbrunn, F. Brianza, F. O. Gombert, C. Ludin, J. W. Vrijbloed, J. P. Obrecht, S. Lociuro, V. Brondani, F. Hamy, T. Klimkait, K. Moehle, J. A. Robinson, D. Obrecht. Chimia, 2007, 61, 147-150.

(a) R. Fasan, R. L. Dias, K. Moehle, O. Zerbe, J. W. Vrijbloed, D. Obrecht, J. A. Robinson. 
Angew. Chem., Int. Ed. Engl., 2004, 43, 2109-2112; (b) J. A. Robinson. Acc. Chem. Res., 2008, 41, 1278-1288.

G. Moncunill, M. Armand-Ugón, I. Clotet-Codina, E. Pauls, E. Ballana, A. Llano, B. Romagnoli, J. W. Vrijbloed, F. O. Gombert, B. Clotet, S. De Marco, J. A. Esté. Mol. Pharmacol., 2008, 73, 1264-1273.

58 S. J. Demarco, R. Mukherjee, K. Moehle, J. A. Robinson, H. Henze, B. Romagnoli, D. Obrecht, F. Gombert, C. Ludin, J. W. Vrijbloed. PCT Int. Appl. 2008, WO 2008104090.

59 F. O. Gombert, D. Obrecht, A. Lederer, B. Romagnoli. PCT Int. Appl. 2010, WO 2010060479.

60 D. Obrecht, F. O. Gombert, A. Lederer, B. Romagnoli, C. Bisang. PCT Int. Appl. 2010, WO 2010127704.

61 S. Barthelemy, C. Bisang, F. O. Gombert, A. Lederer, D. Obrecht, B. Romagnoli, J. Zumbrunn, T. Remus, G. Lemercier. PCT Int. Appl. 2011, WO 2011066869.

62 M. P. Crump, J. H. Gong, P. Loetscher, K. Rajarathnam, A. Amara, F. Arenzana-Seisdedos, J. L. Virelizier, M. Baggiolini, B. D. Sykes, I. Clark-Lewis. EMBO J., 1997, 16, 6996-7007.

63 C. Dealwis, E. J. Fernandez, D. A. Thompson, R. J. Simon, M. A. Siani, E. Lolis. Proc. Natl. Acad. Sci. USA., 1998, 95, 6941-6946.

64 N. Heveker, M. Montes, L. Germeroth, A. Amara, A. Trautmann, M. Alizon, J. Schneider-Mergener. Curr. Biol., 1998, 8, 369-376.

65 Y. Tan, Y. Li, J. Xiao, H. Shao, C. Ding, G. E. Arteel, K. A. Webster, J. Yan, H. Yu, L. Cai, X. Li. Cardiovasc. Res., 2009, 82, 513-521.

66 A. Sachpatzidis, B. K. Benton, J. P. Manfredi, H. Wang, A. Hamilton, H. G. Dohlman, E. Lolis. J. Biol. Chem., 2003, 278, 896-907.

67 Z. Luo, N. Zhou, J. Luo, J. W. Hall, Z. Huang. Biochem. Biophys. Res. Commun., 1999, 263, 691-695.

68 J. Luo, Z. Luo, N. Zhou, J. W. Hall, Z. Huang. Biochem. Biophys. Res. Commun., 1999, 264, $42-47$.

69 C. Tudan, G. E. Willick, S. Chahal, L. Arab, P. Law, H. Salari, A. Merzouk. J. Med. Chem., 2002, 45, 2024-2031.

70 R. Zhong, P. Law, D. Wong, A. Merzouk, H. Salari, E. D. Ball. Exp. Hematol., 2004, 32, 470-475.

71 P. Loetscher, J. H. Gong, B. Dewald, M. Baggiolini, I. Clark-Lewis. J. Biol. Chem., 1998, 273, 22279-22283.

72 E. L. Elisseeva, C. M. Slupsky, M. P. Crump, I. Clark-Lewis, B. D. Sykes. J. Biol. Chem., 2000, 275, 26799-26805.

73 A. Faber, C. Roderburg, F. Wein, R. Saffrich, A. Seckinger, K. Horsch, A. Diehlmann, D. Wong, 
G. Bridger, V. Eckstein, A. D. Ho, W. Wagner. J. Biomed. Biotechnol., 2007, 2007, 26065.

S. Y. Kim, C. H. Lee, B. V. Midura, C. Yeung, A. Mendoza, S. H. Hong, L. Ren, D. Wong, W. Korz, A. Merzouk, H. Salari, H. Zhang, S. T. Hwang, C. Khanna, L. J. Helman. Clin. Exp. Metastasis, 2008, 25, 201-211.

75 (a) M. M. Richert, K. S. Vaidya, C. N. Mills, D. Wong, W. Korz, D. R. Hurst, D. R. Welch. Oncol. Rep., 2009, 21, 761-767; (b) E. H. Huang, B. Singh, M. Cristofanilli, J. Gelovani, C. Wei, L. Vincent, K. R. Cook, A. Lucci. J. Surg. Res., 2009, 155, 231-236; (c) B. Singh, K. R. Cook, C. Martin, E. H. Huang, K. Mosalpuria, S. Krishnamurthy, M. Cristofanilli, A. Lucci. Clin. Exp. Metastasis., 2010, 27, 233-240); (d) S. Hassan, M. Buchanan, K. Jahan, A. Aguilar-Mahecha, L. Gaboury, W. J. Muller, Y.Alsawafi, A. A. Mourskaia, P. M. Siegel, O. Salvucci, M. Basik Int. J. Cancer., 2011, 129, 225-232.

76 (a) J. Kwong, H. Kulbe, D. Wong, P. Chakravarty, F. Balkwill. Mol. Cancer Ther., 2009, 8, 1893-1905; (b) S. Porvasnik, N. Sakamoto, S. Kusmartsev, E. Eruslanov, W. J. Kim, W. Cao, C. Urbanek, D. Wong, S. Goodison, C. J. Rosser. Prostate, 2009, 69, 1460-1469.

77 (a) T. N. Kledal, M. M. Rosenkilde, F. Coulin, G. Simmons, A. H. Johnsen, S. Alouani , C. A. Power, H. R. Lüttichau, J. Gerstoft, P. R. Clapham, I. Clark-Lewis, T. N. Wells, T. W. Schwartz. Science, 1997, 277, 1656-1659; (b) C. Boshoff, Y. Endo, P. D. Collins, Y. Takeuchi, J. D. Reeves, V. L. Schweickart, M. A. Siani, T. Sasaki, T. J. Williams, P. W. Gray, P. S. Moore, Y. Chang, R. A. Weiss. Science, 1997, 278, 290-294.

78 N. Zhou, Z. Luo, J. Luo, J. W. Hall, Z. Huang. Biochemistry, 2000, 39, 3782-3287.

79 Z. Luo, X. Fan, N. Zhou, M. Hiraoka, J. Luo, H. Kaji, Z. Huang. Biochemistry, 2000, 39, 13545-13550.

80 M. P. Crump, E. Elisseeva, J. Gong, I. Clark-Lewis, D. Brian. B. D. Sykes. FEBS Lett., 2001, 489, 171-175.

81 N. Zhou, Z. Luo, J. Luo, X. Fan, M. Cayabyab, M. Hiraoka, D. Liu, X. Han, J. Pesavento, C. Z. Dong, Y. Wang, J. An, H. Kaji, J. G. Sodroski, Z. Huang. J. Biol. Chem., 2002, 277, 17476-17485.

82 M. Mori, D. Liu, S. Kumar, Z. Huang. Biochem. Biophys. Res. Commun., 2005, 335, 651-658.

83 C. Z. Dong, S. Kumar, W. T. Choi, N. Madani, S. Tian, J. An, J. G. Sodroski, Z. Huang. J. Med. Chem., 2005, 48, 7923-7924.

84 W. T. Choi, S. Tian, C. Z. Dong, S. Kumar, D. Liu, N. Madani, J. An, J. G. Sodroski, Z. Huang. J. Virol., 2005, 79, 15398-15404.

85 L. Covic, M. Misra, J. Badar, C. Singh, A. Kuliopulos. Nat. Med., 2002, 8, 1161-1165.

86 B. Tchernychev, Y. Ren, P. Sachdev, J. M. Janz, L. Haggis, A. O'Shea, E. McBride, R. Looby, Q. Deng, T. McMurry, M. A. Kazmi, T. P. Sakmar, S. Hunt, III, K. E. Carlson. Proc. Natl. Acad. Sci. 
USA., 2010, 107, 22255-22259.

87

88

M. L. Marotta, M. Mirza, B. Jiang, P. Kiser, K. Medvik, S. F. Sieg, A. Weinberg AIDS. 17, F39-F48 (2003); (b) Z. Feng, G. R. Dubyak, M. M. Lederman, A. Weinberg J. Immunol., 2006, 177, $782-786$. 3216-3220.

A. Y. Lin, C. Seibert, T. McMurry, K. E. Carlson, T. W.Muir, S. Hunt, III, T. P. Sakmar. J. Am. Chem. Soc., 2011, 133, 15878-15881.

70, 2825-2831.

W. A. O'Brien. J. Exp. Med., 1997, 186, 1395-400.

N. Zhou, J. Fang, E. Acheampong, M. Mukhtar, R. J. Pomerantz. Virology, 2003, 312, 196-203.

C. Boggiano, S. Jiang, H. Lu, Q. Zhao, S. Liu, J. Binley, S. E. Blondelle. Biochem. Biophys. Res. Commun., 2006, 347, 909-915.

H. Hanaoka, T. Mukai, H. Tamamura, T. Mori, S. Ishino, K. Ogawa, Y. Iida, R. Doi, N. Fujii, H. Saji. Nucl. Med. Biol., 2006, 33, 489-494.

R. Masuda, S, Oishi. H. Ohno, H. Kimura, H. Saji, N. Fujii. Bioorg. Med. Chem., 2011, 19,

(a) J. Kuil, T. Buckle, H. Yuan, N. S. van den Berg, S. Oishi, N. Fujii, L. Josephson, F. W. van Leeuwen. Bioconjug. Chem., 2011, 22, 859-864; (b) J. Kuil, T. Buckle, J. Oldenburg, H. Yuan, A. D. Borowsky, L. Josephson, F. W. van Leeuwen. Mol Pharm., 2011, 8, 2444-2453.

96 E. Garanger, E. Aikawa, F. Reynolds, R. Weissleder, L. Josephson. Chem. Commun., 2008, $4792-4794$.

97 O. Jacobson, I. D. Weiss, L. P. Szajek, G. Niu, Y. Ma, D. O. Kiesewetter, J. M. Farber, X. Chen. Theranostics., 2011, 1, 251-262.

98 O. Jacobson, I. D. Weiss, L. P. Szajek, G. Niu, Y. Ma, D. O. Kiesewetter, A. Peled, H. S. Eden, J. M. Farber, X. Chen J. Control. Release, 2012, 157, 216-223.

99 O. Jacobson, I. D. Weiss, D. O. Kiesewetter, J. M. Farber, X. Chen. J. Nucl. Med., 2010, 51, 1796-1804.

100 O. Demmer, E. Gourni, U. Schumacher, H. Kessler, H. J. Wester. ChemMedChem, 2011, 6, 1789-1791.

101 E. Gourni, O. Demmer, M. Schottelius, C. D'Alessandria, S. Schulz, I. Dijkgraaf, U. Schumacher, M. Schwaiger, H. Kessler, H. J. Wester J. Nucl. Med., 2011, 52, 1803-1810.

102 A. Dar, P. Goichberg, V. Shinder, A. Kalinkovich, O. Kollet, N. Netzer, R. Margalit, M. Zsak, A. 
Nagler, I. Hardan, I. Resnick, A. Rot, T. Lapidot. Nat. Immunol., 2005, 6, 1038-1046.

103 S. Hatse, K. Princen, S. Liekens, K. Vermeire, E. De Clercq, D. Schols. Cytometry A., 2004, 61A, 178-188.

104 A. E. Strong, A. C. Thierry, P. Cousin, C. Moulon, S. Demotz. Eur. Cytokine Netw., 2006, 17, 49-59.

105 S. Oishi, R. Masuda, B. Evans, S. Ueda, Y. Goto, H. Ohno, A. Hirasawa, G. Tsujimoto, Z. Wang, S. C. Peiper, T. Naito, E. Kodama, M. Matsuoka, N. Fujii. ChemBiochem, 2008, 9, 1154-1158.

106 K. Nishizawa, H. Nishiyama, S. Oishi, N. Tanahara, H. Kotani, Y. Mikami, Y. Toda, B. J. Evans, S. C. Peiper, R. Saito, J. Watanabe, N. Fujii, O. Ogawa. Int. J. Cancer., 2010, 127, 1180-1187.

107 W. Nomura, Y. Tanabe, H. Tsutsumi, T. Tanaka, K. Ohba, N. Yamamoto, H. Tamamura. Bioconjug. Chem., 2008, 19, 1917-1920.

108 N. S. van den Berg, T. Buckle, J. Kuil, J. Wesseling, F. W. van Leeuwen. Transl. Oncol., 2011, 4, 234-240.

109 J. Kuil, P. Steunenberg, P. T. Chin, J. Oldenburg, A. H. Jalink A. H., A. H. Velders, F. W. van Leeuwen. ChemBiochem, 2011, 12, 1897-1903.

110 K. Balabanian, B. Lagane, S. Infantino, K. Y. Chow, J. Harriague, B. Moepps, F. Arenzana-Seisdedos, M. Thelen, F. Bachelerie. J. Biol. Chem., 2005, 280, 35760-35766.

111 J. M. Burns, B. C. Summers, Y. Wang, A. Melikian, R. Berahovich, Z. Miao, M.E. Penfold, M. J. Sunshine, D. R. Littman, C. J. Kuo, K. Wei, B. E. McMaster, K. Wright, M. C. Howard, T. J. Schall J. Exp. Med., 2006, 203, 2201-2213.

112 For reviews, see: (a) X. Sun, G. Cheng, M. Hao, J. Zheng, X. Zhou, J. Zhang, R. S. Taichman, K. J. Pienta, J. Wang. Cancer Metastasis Rev., 2010, 29, 709-722; (b) D. G. Duda, S. V. Kozin, N. D. Kirkpatrick, L. Xu, D. Fukumura, R. K. Jain. Clin. Cancer Res., 2011, 17, 2074-2080. 
Table 1. Polyphemusin II-derived CXCR4 antagonists

\begin{tabular}{|c|c|c|}
\hline peptide & sequence $^{a}$ & ref \\
\hline tachyplesin I & $\mathrm{H}-\mathrm{KWC} C^{1}$ FRVC $^{2}{ }^{2}$ RGIC ${ }^{2}$ YRRC $^{1} \mathrm{R}-\mathrm{NH}_{2}\left(\mathrm{C}^{1}-\mathrm{C}^{1} / \mathrm{C}^{2}-\mathrm{C}^{2}\right.$ bridged $)$ & 9 \\
\hline polyphemsin II & 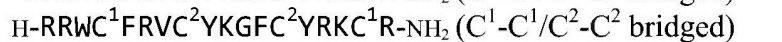 & 11 \\
\hline $\mathrm{T} 22$ & H-RRWC ${ }^{1} Y_{R K C}{ }^{2} Y K G Y C^{2} Y_{R K C}^{1}{ }^{1}-N_{2}\left(C^{1}-C^{1} / C^{2}-C^{2}\right.$ bridged $)$ & 11,12 \\
\hline TW70 & H-RRWCYRKKPYRKCR-NH $\mathrm{N}_{2}(\mathrm{C}-\mathrm{C}$ bridged $)$ & 22 \\
\hline T134 & H-RRWCYRKKPYRX ${ }^{2}$ CR-OH (C-C bridged) & 24 \\
\hline T140 & H-RRX ${ }^{1}$ CYRKKPYRX ${ }^{2}$ CR-OH (C-C bridged $)$ & 26 \\
\hline TN14003 & $\mathrm{H}-\mathrm{RRX}^{1} \mathrm{CYX}{ }^{2} \mathrm{KKPYRX}{ }^{2} \mathrm{CR}-\mathrm{NH}_{2}$ (C-C bridged $)$ & 34 \\
\hline TC14012 & $\mathrm{H}-\mathrm{RRX}^{1} \mathrm{CYX} \mathrm{X}^{2} \mathrm{KX}^{2} \mathrm{PYRX} \mathrm{X}^{2} \mathrm{CR}-\mathrm{NH}_{2}$ (C-C bridged $)$ & 34 \\
\hline TE14011 & $\mathrm{H}-\mathrm{RRX}^{1} \mathrm{CYX}{ }^{2} \mathrm{KePYRX}{ }^{2} \mathrm{CR}-\mathrm{NH}_{2}$ (C-C bridged) & 35 \\
\hline TF 14016 & $4 \mathrm{FB}-\mathrm{RRX}^{1} \mathrm{CYX} \mathrm{KKKPYRX}^{2} \mathrm{CR}-\mathrm{NH}_{2}$ (C-C bridged $)$ & 36 \\
\hline FC131 & cyclo(-D-Tyr-Arg-Arg-Nal-Gly-) [Figure 2] & 47 \\
\hline FC122 & cyclo(-D-Tyr-D-MeArg-Arg-Nal-Gly-) [Figure 2] & $48 \mathrm{c}$ \\
\hline FCA004 & cyclo(-D-Tyr-Arg-Arg-Nal- $\psi[\mathrm{C}(=\mathrm{NH})-\mathrm{NH}]-\mathrm{Gly}-)$ [Figure 2] & 51 \\
\hline
\end{tabular}

Table 2. CXCR4 ligands derived from SDF-1 sequence

\begin{tabular}{|c|c|c|c|}
\hline peptide & sequence & agonist/antagonist & ref \\
\hline SDF-1(2-67) & & antagonist & 62 \\
\hline SDF-1(3-67) & & antagonist & 62 \\
\hline SDF K1R & & antagonist & 62 \\
\hline SDF P2G & & antagonist & 62 \\
\hline $\mathrm{SDF}-1 \beta \mathrm{P} 2 \mathrm{G}$ & & antagonist & 65 \\
\hline SDF-1(1-13) & KPVSLSYRCPCRF & agonist & 64 \\
\hline $\mathrm{L} 5 \mathrm{H}$ & KPVSHSYRCPCRF & antagonist & 64 \\
\hline RSVM & RSVMLSYRCPCRFFESH & partial agonist & 66 \\
\hline ASLW & ASLWLSYRCPCRFFESH & superagonist & 66 \\
\hline SD-2 & KPVSLSYRCPCRFF-AAAA-RARLKAKLHK & $-a^{a}$ & 67 \\
\hline SD-4 & KPVSLSYRCPCRFF-GGGG-RRRRRRRRR & agonist & 67 \\
\hline NCT-tide & LSYRCPCRFF-GGGG-LKWIQEYLEKALN & agonist & 68 \\
\hline CTCE0021 & KPVSLSYRCPCRFF-GGGG-LKWIQEYLEKALN ${ }^{b}$ & agonist & 69,70 \\
\hline 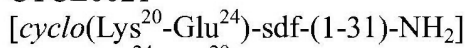 & & & \\
\hline cyclo $\left(\mathrm{Glu}^{24}-\mathrm{Lys}^{28}\right)$-sdf-(1-31)-NH & KPVSLSYRCPCRFF-GGGG-LKWIQEYLEKALN ${ }^{b}$ & agonist & 69 \\
\hline CTCE0214 & KPVSLSYRAPFRFF-GGGG-LKWIQEYLEKALN ${ }^{b}$ & agonist & 70 \\
\hline SDF-1(1-9) & KPVSLSYRC & agonist & 71 \\
\hline SDF-1(1-9) dimer & $(\text { KPVSLSYRC })_{2}$ & agonist & 71 \\
\hline SDF-1(1-9) P2G dimer & $(\text { KGVSLSYRC })_{2}$ & antagonist & 71 \\
\hline CTCE-9908 & $\left(\right.$ KGVSLSYR) ${ }_{2} \mathrm{~K}$ & antagonist & 73 \\
\hline
\end{tabular}

${ }^{a}$ No information of the receptor activation. ${ }^{b}$ Cyclic peptide by lactamization between Lys and Glu shown in bold. 
Table 3. Miscellaneous CXCR4 ligands

\begin{tabular}{llcc}
\hline peptide & sequence & agonist/antagonist & ref \\
\hline vMIP-II & & antagonist & 77 \\
V1 [vMIP-II(1-21)] & LGASWHRPDKCLGYQKRPLP & antagonist & 78 \\
V1-C11A & LGASWHRPDKACLGYQKRPLP & $-{ }^{a}$ & 79 \\
V1-C11F & LGASWHRPDKFCLGYQKRPLP & $-{ }^{-}$ & 79 \\
vMIP-II(1-11) dimer & (LGASWHRPDKC) & & 80 \\
DV1 & lgaswhrpdkcclgyqkrplp & antagonist & 81 \\
DV3 & lgaswhrpdk & antagonist & 81 \\
RCP222 & & antagonist & 83 \\
[D-vMIP-II(1-10)-SDF-1(9-68)] & & & \\
ATI-2341 & palmitoyl-MGYQKKLRSMTDKYRL & agonist & 86 \\
ALX40-4C & Ac-rrrrrrrrr & antagonist & 88 \\
DC13 & Ac-rrmyrriyrr & antagonist & 91 \\
$\beta$-defensin 3 (hBD3) & & antagonist & 92 \\
\hline
\end{tabular}

${ }^{a}$ No information of the receptor activation.

Table 4. Imaging probes for CXCR4

\begin{tabular}{|c|c|c|}
\hline peptide & sequence $^{a}$ & ref \\
\hline In-DTPA-Ac-TZ14011 & 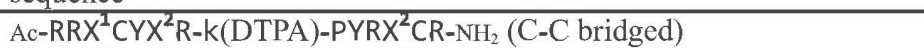 & 93,94 \\
\hline In-DTPA-TN14003 & Ac-RRX ${ }^{1} \mathrm{CY} X^{2} \mathrm{~K}-\mathrm{k}(\mathrm{DTPA})-\mathrm{PYRX}^{2} \mathrm{CR}-\mathrm{NH}_{2}$ (C-C bridged) & 94 \\
\hline In-DTPA-TF14016 & 4 FB-RRX ${ }^{1} \mathrm{CYX}{ }^{2} \mathrm{~K}-\mathrm{K}(\mathrm{DTPA})-\mathrm{PYRX}{ }^{2} \mathrm{CR}-\mathrm{NH}_{2}(\mathrm{C}-\mathrm{C}$ bridged $)$ & 94 \\
\hline Ac-TZ14011-MSAP & Ac-RRX ${ }^{1} \mathrm{CYX}^{2} \mathrm{R}-\mathrm{k}($ linker-DTPA/CyAL-5.5 $)-\mathrm{PYRX}^{2} \mathrm{CR}-\mathrm{NH}_{2}$ (C-C bridged $)$ & 95 \\
\hline T140-2D & $4 \mathrm{FB}-\mathrm{RRX}{ }^{1} \mathrm{CYX}{ }^{2}-\mathrm{K}(\mathrm{DOTA})-\mathrm{k}(\mathrm{DOTA})-\mathrm{PYRX}{ }^{2} \mathrm{CR}-\mathrm{NH}_{2}(\mathrm{C}-\mathrm{C}$ bridged $)$ & 97 \\
\hline DOTA-NFB & DOTA-RRX ${ }^{1} \mathrm{CY} \mathrm{X}^{2} \mathrm{KKPYRX}{ }^{2} \mathrm{CR}-\mathrm{NH}_{2}$ (C-C bridged) & 98 \\
\hline NOTA-NFB & NOTA-RRX ${ }^{1} \mathrm{CY} X^{2} \mathrm{KkPYRX}^{2} \mathrm{CR}-\mathrm{NH}_{2}(\mathrm{C}-\mathrm{C}$ bridged $)$ & 98 \\
\hline $4-{ }^{18} \mathrm{~F}-\mathrm{T} 140$ & $\left({ }^{18} \mathrm{~F}-4 \mathrm{FB}\right)-\mathrm{RRX}{ }^{1} \mathrm{CYX}{ }^{2} \mathrm{KkPYRX}{ }^{2} \mathrm{CR}-\mathrm{NH}_{2}(\mathrm{C}-\mathrm{C}$ bridged $)$ & 99 \\
\hline${ }^{68} \mathrm{Ga}-\mathrm{CPCR} 4-2$ & see Figure 6 & 100,101 \\
\hline${ }^{68} \mathrm{Ga}-25$ & see Figure 6 & $52 \mathrm{~b}$ \\
\hline FITC-SDF-1 & & 102 \\
\hline CXCL12 $12^{\mathrm{AF} 647}$ & & 103 \\
\hline TY14003 & Ac-RRX ${ }^{1} \mathrm{CYX}{ }^{2} \mathrm{R}-\mathrm{k}(\mathrm{FL})-\mathrm{PYRX}{ }^{2} \mathrm{CR}-\mathrm{NH}_{2}(\mathrm{C}-\mathrm{C}$ bridged $)$ & 105 \\
\hline TAMRA-Ac-TZ14011 & Ac-RRX ${ }^{1} C Y X^{2} R-k$ (Acp-TAMRA)-PYRX ${ }^{2} C R-\mathrm{NH}_{2}$ (C-C bridged) & 107 \\
\hline Ac-TZ14011-FITC & Ac-RRX ${ }^{1} C Y X^{2} R-k\left(\right.$ FITC)-PYRX ${ }^{2} C R-\mathrm{NH}_{2}(\mathrm{C}-\mathrm{C}$ bridged $)$ & 108 \\
\hline
\end{tabular}

${ }^{a} \mathrm{X}^{1}$ : L-3-(2-naphthyl)alanine; $\mathrm{X}^{2}$ : L-citrulline; 4FB: 4-fluorobenzoyl; FL: carboxyfluorescein; Acp: 6-aminohexanoic acid; TAMRA: tetramethylrhodamine; FITC: fluoresceinisothiocyanate; DTPA: diethylenetriaminepentaacetic acid; DOTA: 1,4,7,10-tetraazacyclododecane-1,4,7,10-tetraacetic acid; NOTA: 1,4,7-triazacyclononane-1,4,7-triacetic acid. 
Figure 1. Crystal structure of CXCR4 in complex with a T140 analogue peptide, CVX15 (PDB code: 3OE0). (a) CVX15-CXCR4 interaction in the receptor pocket. (b) Charge interactions between CVX15 and CXCR4.
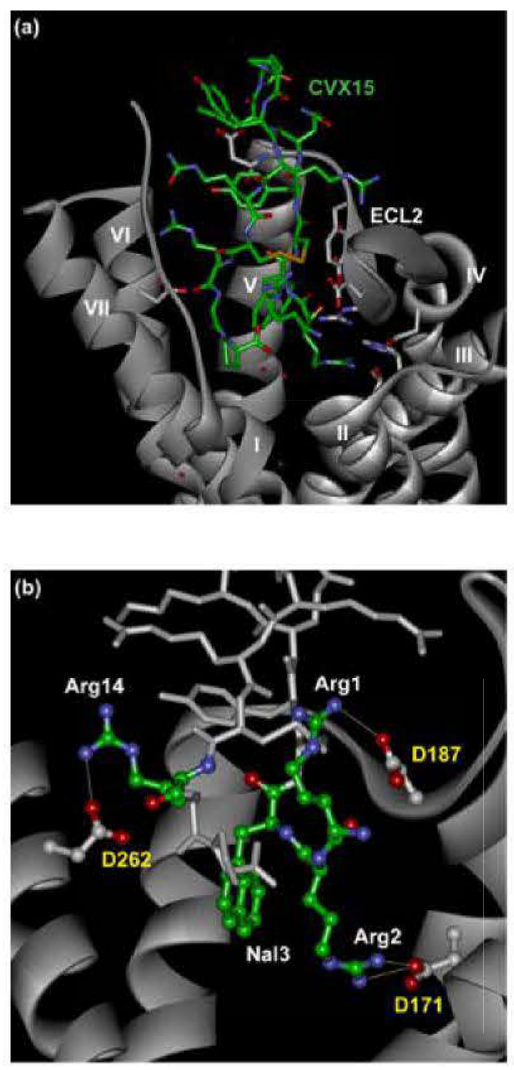
Figure 2. Structure of peptidomimetic analogues of FC131.
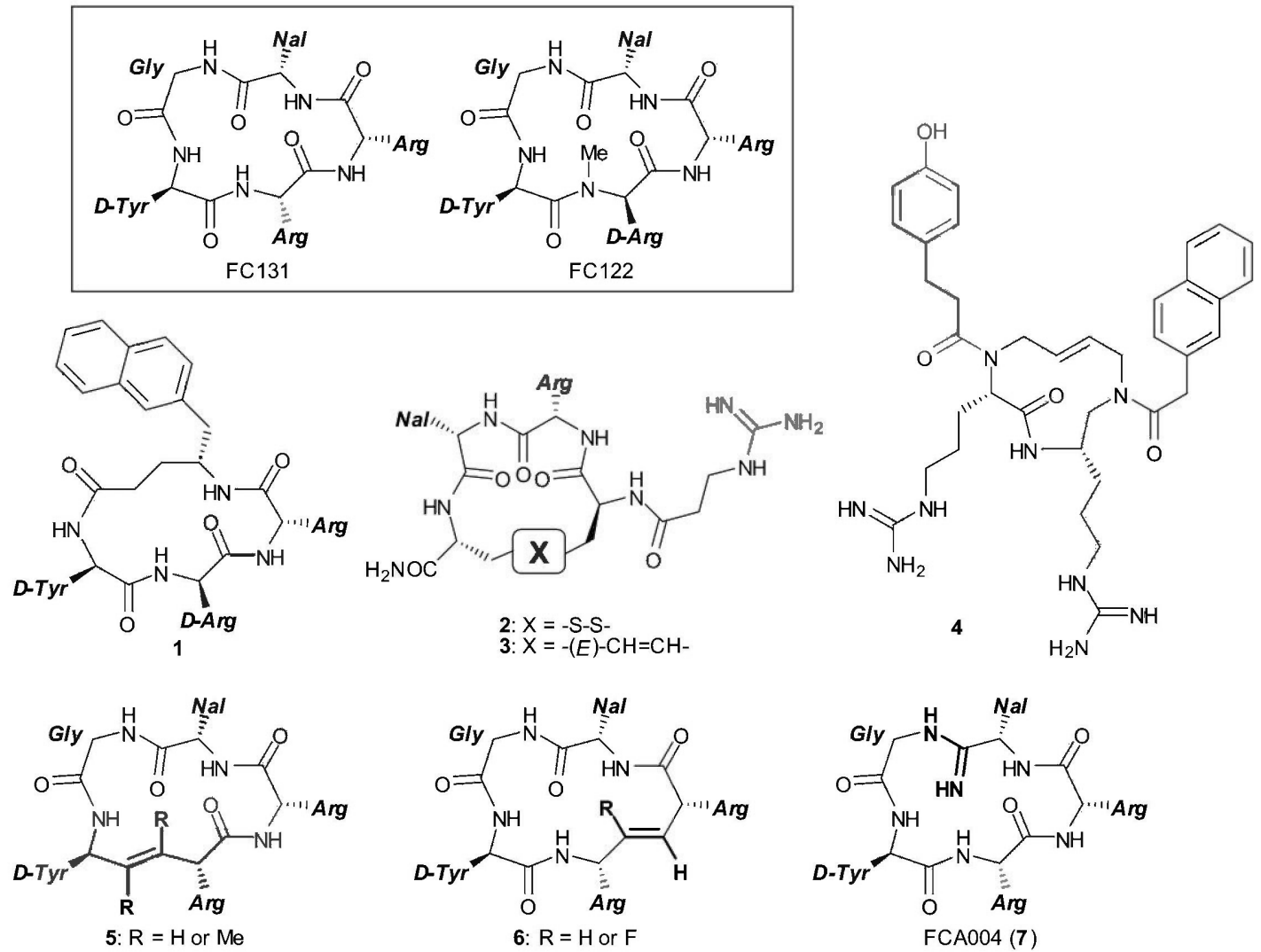
Figure 3. Binding modes of FC131 (a) and FC122 (b) with CXCR4.

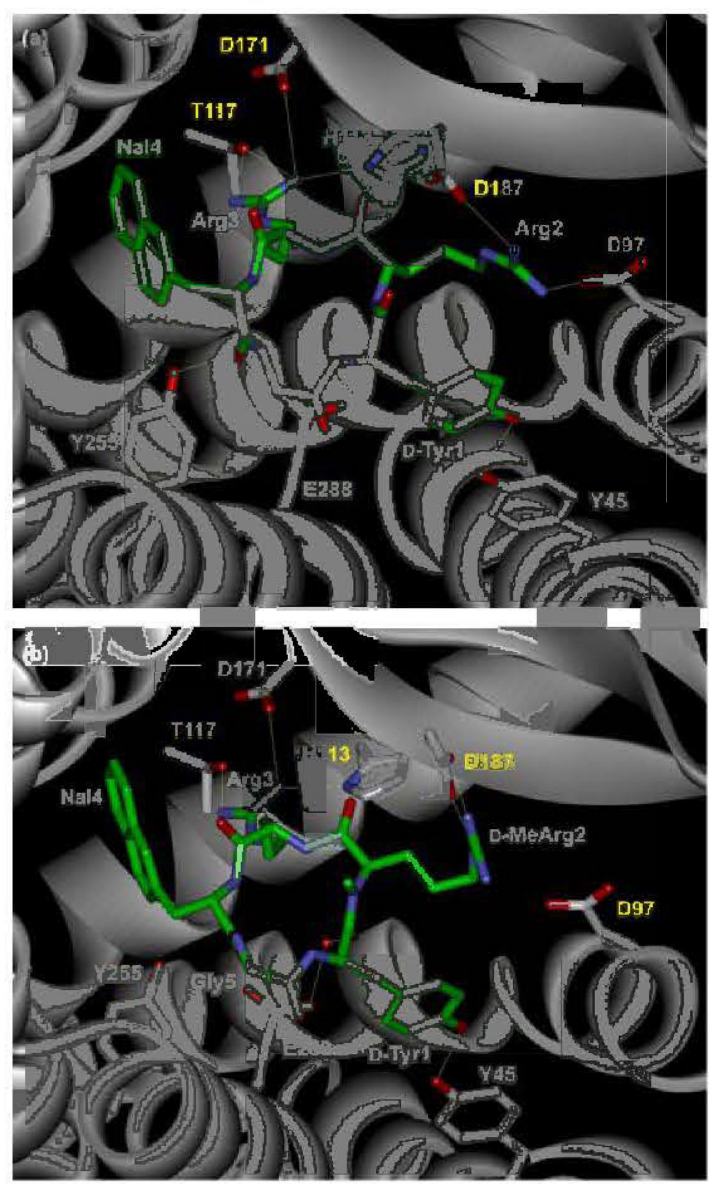


Figure 4. Structures of $\beta$-hairpin peptidomimetic CXCR4 antagonists. Abbreviations: L-3-(2-naphthyl)alanine; Cit: L-citrulline; Dab: L-2,4-diaminobutyric acid; Ahb: (S)-4-amino-2-hydroxybutyric acid; (Abu)Gly: $N$-(4-amino- $n$-butyl)glycine; Lac: lactic acid.
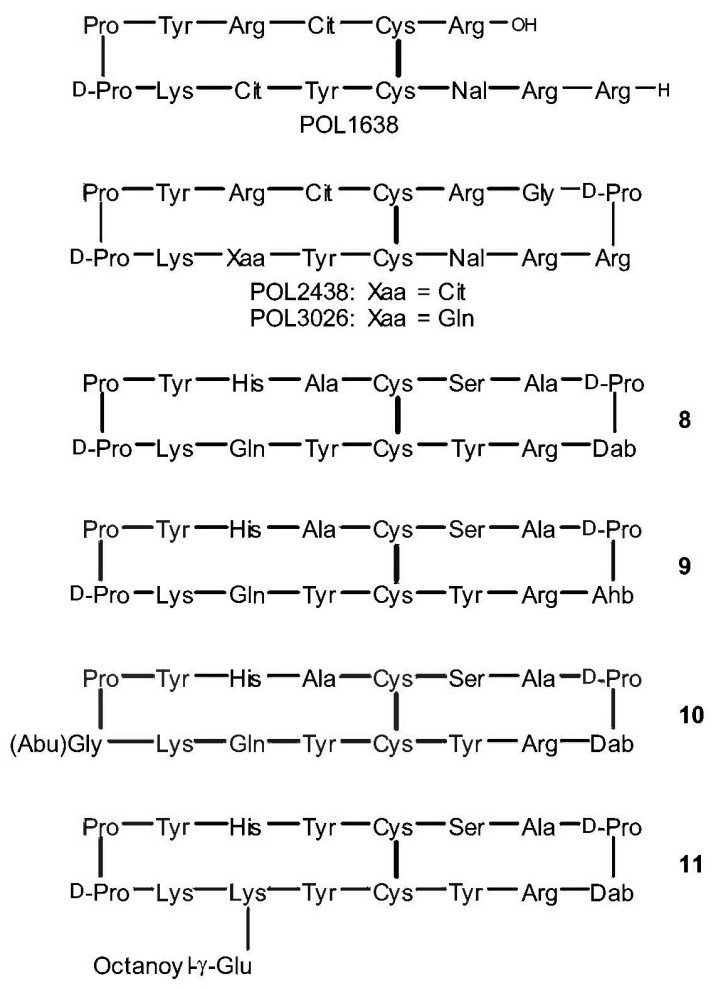
Figure 5. Structures of metal-chelating and labeling functional groups for imaging probes.<smiles>CC(C)(C)CN(CCN(CCN(CC(=O)O)CC(=O)O)CC(=O)O)CC(=O)O</smiles>

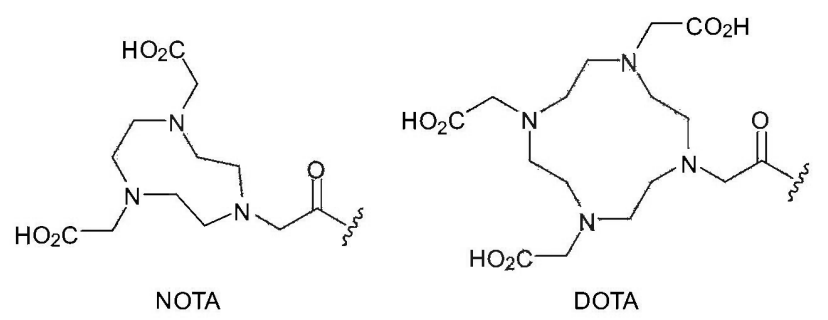

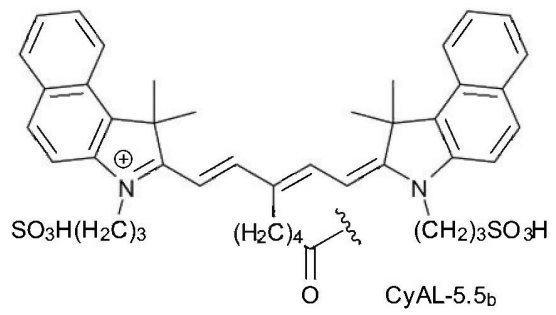

Figure 6. Structures of FC131-based imaging probes.
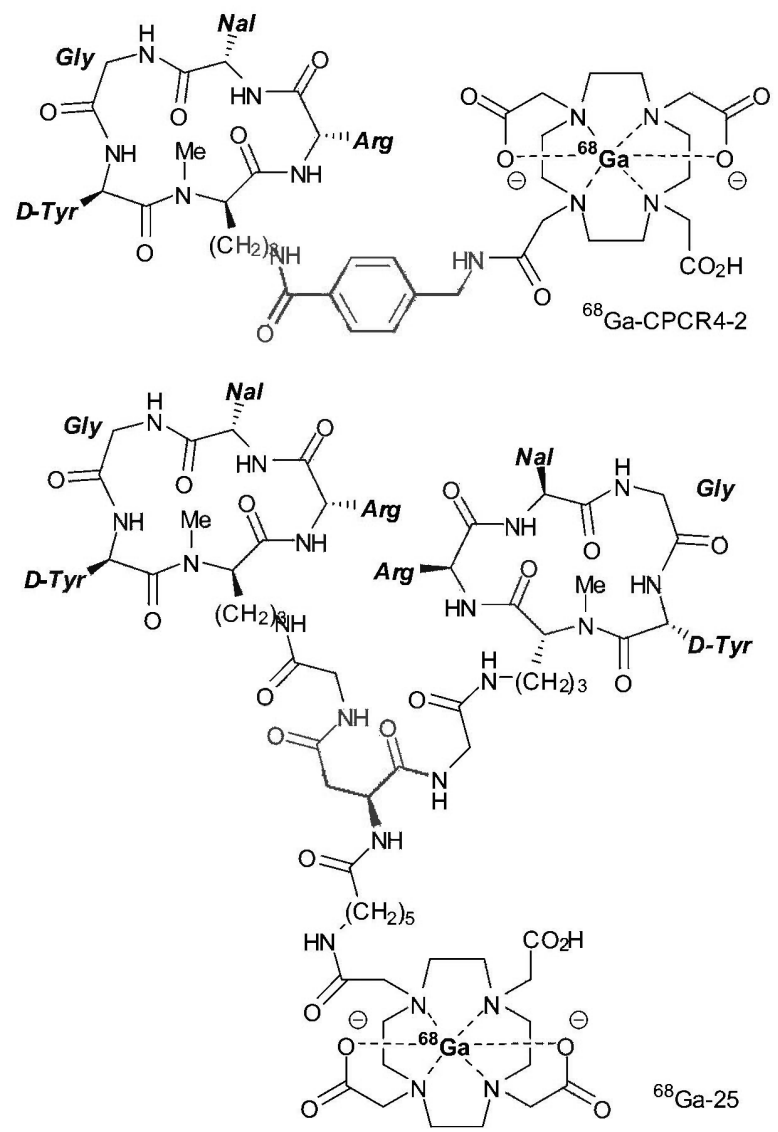


\section{Table of Contents Entry}

$$
\begin{aligned}
& \begin{array}{r}
\mathrm{H}-\mathrm{Arg}-\mathrm{Arg}-\mathrm{Nal}-\mathrm{Cys}-\mathrm{Tyr}-\mathrm{Gln}-\mathrm{Lys}-\mathrm{D}-\mathrm{Lys} \\
\mathrm{HO}-\mathrm{Arg}-\mathrm{Cys}-\mathrm{Cit}-\mathrm{Arg}-\mathrm{Tyr}-\mathrm{Pro}
\end{array} \\
& \text { T140 }
\end{aligned}
$$

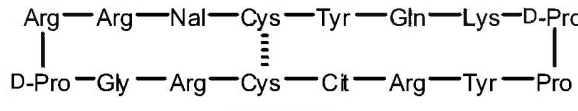

$$
\begin{aligned}
& \text { POL3026 }
\end{aligned}
$$

This perspective article highlights the recent developments of peptide and peptidomimetic ligands for CXC chemokine receptor 4 (CXCR4). 